\title{
Entry of Alphaherpesviruses
}

\author{
Tina M. Cairns ${ }^{1}$ and Sarah A. Connolly ${ }^{2 *}$
}

${ }^{1}$ Department of Microbiology, School of Dental Medicine, University of

Pennsylvania, Philadelphia, Pennsylvania, USA

2Departments of Health Sciences and Biological Sciences, College of Science and Health, DePaul University, Chicago, Illinois, USA

*sarah.connolly@depaul.edu

DOI: https://doi.org/10.21775/cimb.041.063

\begin{abstract}
Alphaherpesviruses are enveloped viruses that enter cells by fusing the viral membrane with a host cell membrane, either within an endocytic vesicle or at the plasma membrane. This entry event is mediated by a set of essential entry glycoproteins, including glycoprotein $\mathrm{D}(\mathrm{gD}), \mathrm{gHgL}$, and $\mathrm{gB}$. gHgL and $\mathrm{gB}$ are conserved among herpesviruses, but $\mathrm{gD}$ is unique to the alphaherpesviruses and is not encoded by all alphaherpesviruses. $\mathrm{gD}$ is a receptor-binding protein, the heterodimer $\mathrm{gHgL}$ serves as a fusion regulator, and $\mathrm{gB}$ is a class III viral fusion protein. Sequential interactions among these glycoproteins are thought to trigger the virus to fuse at the right place and time. Structural studies of these glycoproteins from multiple alphaherpesviruses has enabled the design and interpretation of functional studies. The structures of $\mathrm{gD}$ in a receptorbound and in an unliganded form reveal a conformational change in the $\mathrm{C}$ terminus of the $\mathrm{gD}$ ectodomain upon receptor binding that may serve as a signal for fusion. By mapping neutralizing antibodies to the $\mathrm{gHgL}$ structures and constructing interspecies chimeric forms of $\mathrm{gHgL}$, interaction sites for both $\mathrm{gD}$ and $\mathrm{gB}$ on $\mathrm{gHgL}$ have been proposed. A comparison of the postfusion
\end{abstract}


structure of $\mathrm{gB}$ and an alternative conformation of $\mathrm{gB}$ visualized using cryoelectron tomography suggests that $\mathrm{gB}$ undergoes substantial refolding to execute membrane fusion. Although these structures have provided excellent insights into the entry mechanism, many questions remain about how these viruses coordinate the interactions and conformational changes required for entry.

\section{Introduction}

As the first step of infection, alphaherpesvirus entry requires the coordinated action of several glycoproteins on the viral surface. Unlike many other viruses, herpesviruses encode receptor-binding and membrane fusion functions on separate proteins. These proteins must cooperate to mediate fusion of the viral and cellular membranes at the right time and place, either at the plasma membrane or within an endosome.

Entry proceeds through three basic steps: initial attachment, entry receptor binding, and membrane fusion (Figure 1A). Initial attachment to a cell is mediated typically by glycoprotein $\mathrm{C}(\mathrm{gC})$ and/or gB binding to cell surface proteoglycans (Herold et al., 1994; Herold et al., 1991; Laquerre et al., 1998; Rux et al., 2002). This attachment is reversible and does not trigger membrane fusion or virus entry. Although the attachment enhances infection, it is not required for entry because cells lacking heparan sulfate can be infected, albeit with reduced efficiency (Gruenheid et al., 1993).

After attachment, membrane fusion and virus entry require a set of core entry glycoproteins (Figure 1B). All herpesviruses encode $\mathrm{gH}, \mathrm{gL}$, and $\mathrm{gB}$ and most alphaherpesviruses also encode $\mathrm{gD}$, with the notable exception of varicella zoster virus (VZV). These four glycoproteins are essential for infection and they are sufficient to mediate cell-cell fusion of receptor-bearing cells expressing these glycoproteins (Browne et al., 2001; Cole and Grose, 2003; Muggeridge, 2000; Pertel et al., 2001; Turner et al., 1998). In the current model of alphaherpesviral entry into cells (Figure 1B), gD binding to an entry receptor triggers a conformational change that transmits a signal to the $\mathrm{gHgL}$ 
A.

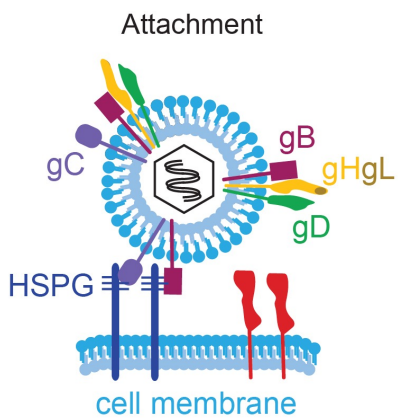

Receptor binding

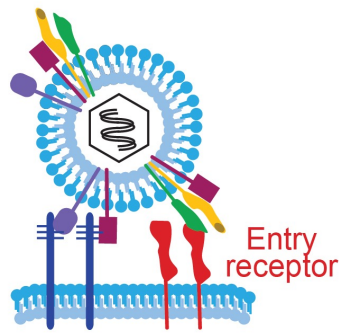

Fusion

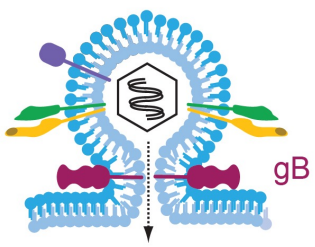

B.

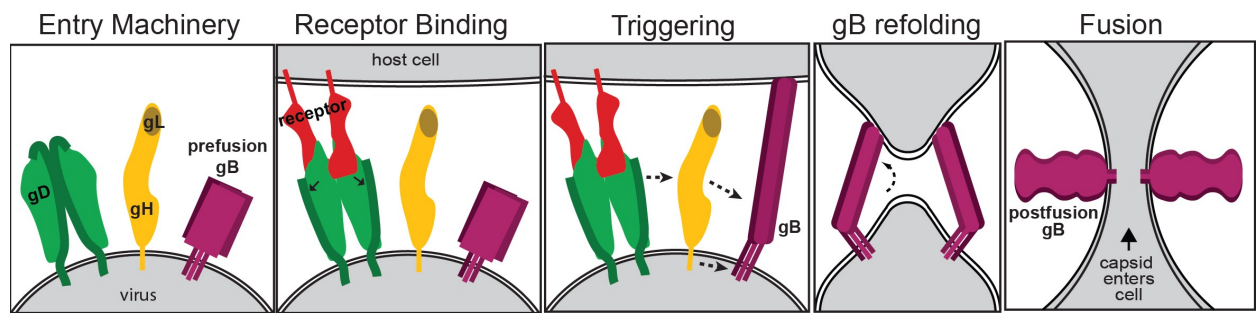

Figure 1. Mechanism of alphaherpesvirus entry. (A) Using HSV as a model for virus entry, heparan sulfate proteoglycans (HSPG), entry receptors, and viral glycoproteins $\mathrm{gB}, \mathrm{gD}, \mathrm{gHgL}$, and $\mathrm{gB}$ are shown. Virus attaches to cells by binding to HSPG via $\mathrm{gC}$ and/or $\mathrm{gB}$. Although this attachment step enhances entry, it is not required for fusion. Attachment is followed by the engagement of entry receptors. With the exception of $\mathrm{VZV}$, this receptor-binding is mediated by $\mathrm{gD}$. Functional $\mathrm{gD}$ receptors include members of the nectin family, HVEM, and 3-O-sulfonated heparan sulfate. In the current model of entry, gD-receptor binding signals $\mathrm{gHgL}$ to trigger $\mathrm{gB}$ to mediate fusion. $\mathrm{gB}$ inserts into the host cell membrane and refolds to fuse the viral and cellular membranes, allowing the viral capsid and genome to enter the host cell. (B) The core entry glycoproteins that are necessary and sufficient for fusion include the receptor-binding protein $\mathrm{gD}$ (green), the $\mathrm{gHgL}$ heterodimer (yellow), and the trimeric fusion protein $\mathrm{gB}$ (purple). Although VZV does not encode a $\mathrm{gD}$ homolog, it does encode $\mathrm{gHgL}$ and $\mathrm{gB}$. Prior to receptor binding, the $\mathrm{C}$-terminus of the $\mathrm{gD}$ ectodomain occludes the receptor-binding site. gD binding to either the HVEM or nectin-1 receptor (red) displaces the $\mathrm{gD} \mathrm{C}$-terminus and transmits a signal to activate $\mathrm{gHgL}$. This signal may come directly from the $\mathrm{gD} \mathrm{C}$-terminal region or as a result the $\mathrm{C}$-terminal repositioning to expose another interaction site on $\mathrm{gD}$. $\mathrm{gHgL}$ then transmits this signal to trigger the fusion protein $\mathrm{gB}$. The interaction with $\mathrm{gB}$ may be mediated by the $\mathrm{gHgL}$ ectodomain and/or the $\mathrm{gH} \mathrm{CT}$. Upon triggering, $\mathrm{gB}$ refolds from a prefusion conformation to insert its fusion loops into the host cell membrane. The orientation of the fusion loops with respect to the viral membrane in the prefusion form of $\mathrm{gB}$ is unresolved. $\mathrm{gB}$ then collapses back on itself, bringing the fusion loops embedded the cell membrane into proximity with the gB TM, thereby fusing the viral and cell membranes. Most likely, more than one $\mathrm{gB}$ trimer must be triggered to create a fusion pore through which the viral capsid can enter the cell, hence two trimers are shown in the later panels. 
heterodimer. $\mathrm{gHgL}$ serves as a regulator of fusion, interacting with both the gDreceptor complex and the viral fusion protein, gB. Through an undefined mechanism, $\mathrm{gHgL}$ triggers the metastable $\mathrm{gB}$ to undergo an extensive refolding event, inserting its hydrophobic fusion loops into the host cell membrane and then folding back on itself to bring the viral and cellular membranes together. Fusion of these membranes creates a lipid pore that permits the viral genome to enter the cell.

Structures of each of the core entry glycoproteins from multiple alphaherpesviruses have been determined. These structures have advanced our understanding of the viral entry mechanism greatly. Using these structures as a framework, this article will review our current knowledge of alphaherpesvirus entry, relating functional studies to the structures and identifying current areas of interest.

\section{Glycoprotein D: Receptor binding}

For most alphaherpesviruses, $\mathrm{gD}$ is the receptor-binding protein and one of the core viral glycoproteins necessary to carry out membrane fusion and cell-cell spread. Two exceptions are VZV, which lacks gD and may instead rely on other glycoproteins for cell surface attachment (see below) (Duus et al., 1995; Maresova et al., 2001; Oliver et al., 2016), and pseudorabies virus (PRV), for which gD is essential for entry but not cell-cell spread (Ch'ng et al., 2007; Klupp and Mettenleiter, 1999; Klupp et al., 2000). Interestingly, with the right selection pressure, replication-competent $\mathrm{gD}$ deletion mutants can be generated in vitro for PRV and bovine herpes virus type 1 (BHV-1) (Schmidt et al., 2001; Schroder and Keil, 1999). These mutant lab strains possess compensatory mutations in $\mathrm{gB}$ and $\mathrm{gH}$ that circumvent the need for $\mathrm{gD}$; however, in wild-type alphaherpesviruses other than VZV, the binding of $\mathrm{gD}$ to specific cellular receptors is required for viral entry. Viral infection can be inhibited by blocking virus-receptor interaction with soluble versions of $\mathrm{gD}$ or the gD receptor ectodomains (Johnson et al., 1990; Montgomery et al., 1996; Nicola et al., 1997; Warner et al., 1998; Whitbeck et al., 1997). In addition, antibodies generated against $\mathrm{gD}$ or the $\mathrm{gD}$ receptors are potent virus 
neutralizers and block membrane fusion (Atanasiu et al., 2018; Cairns et al., 2017; Cocchi et al., 1998; Fuller and Spear, 1987; Highlander et al., 1987; Krummenacher et al., 2000; Lazear et al., 2012; Montgomery et al., 1996; Saw et al., 2015; Whitbeck et al., 2001). Many neutralizing monoclonal antibodies (MAbs) against gD have been generated that block the binding of one or both receptors (Krummenacher et al., 1998; Lee et al., 2013; Nicola et al., 1998; Whitbeck et al., 1999). Additional neutralizing MAbs that do not block receptor binding have been hypothesized to interfere with the ability of $\mathrm{gD}$ to activate gHgL (Atanasiu et al., 2016; Atanasiu et al., 2018; Gallagher et al., 2013; Lazear et al., 2012).

\section{$g D$ receptors}

Three classes of gD entry receptors have been identified, and gD has been cocrystallized with two of these receptors (Figure 2A, B). The first receptor class consists of the nectin and nectin-like proteins, which are immunoglobulin (lg) superfamily members, each having one variable-like (V-like) and two constantlike (C-like) Ig domains (Nakanishi and Takai, 2004). Nectin proteins function as homophilic adhesion molecules and are widely distributed on the surface of most human tissues, including epithelial and neuronal cells, recognized targets for alphaherpesviral infection (Cocchi et al., 1998; Galen et al., 2006; Mata et al., 2001; Mizoguchi et al., 2002; Richart et al., 2003; Takahashi et al., 1999; Warner et al., 1998). The use of nectin-1 as a cell surface receptor is common among alphaherpesviruses. HSV-1, HSV-2, PRV, BHV-1, and herpes B virus all can use nectin-1 for entry (Fan and Longnecker, 2012; Milne et al., 2001; Ono et al., 2004; Warner et al., 1998). HSV and PRV gD bind to nectin-1 with high affinity while the relatively low affinity of BHV-1 for nectin-1 suggests either that low affinity is sufficient for entry or that BHV uses another receptor in its natural host (Connolly et al., 2001; Milne et al., 2001). Nectin-2 has a more limited scope as an alphaherpesvirus receptor and can mediate the entry of PRV, HSV-2, and certain HSV-1 mutants (Lopez et al., 2000; Spear et al., 2006; Warner et al., 1998). Poliovirus receptor (nectin-like molecule 5) permits entry of PRV, BHV-1, and herpes B virus, but not HSV (Fan and Longnecker, 2012; Warner et al., 1998). Under selective pressure, HSV can acquire gain-of- 


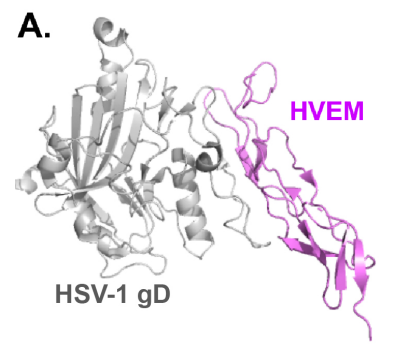

C.

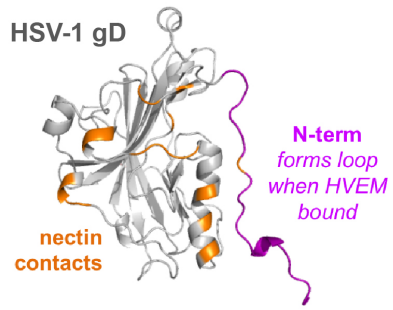

E.

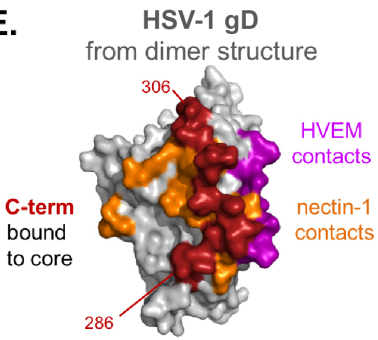

B.

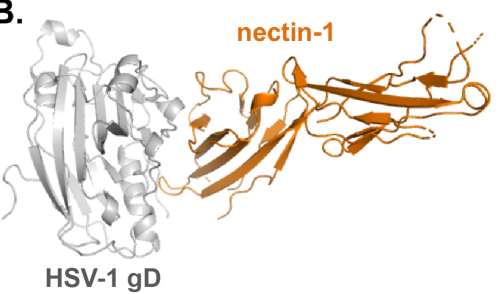

D.

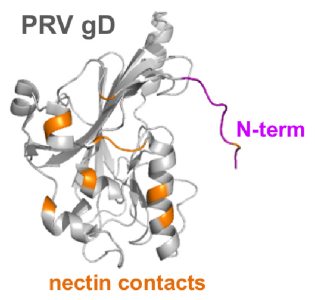

F.

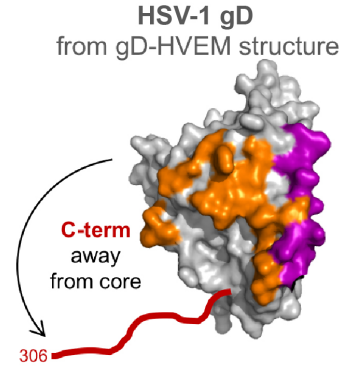

Figure 2. $\mathrm{gD}$ structures. (A) The crystal structure of $\mathrm{gD}$ (gray) bound to HVEM receptor (purple) is shown (PDB 1JMA) (Carfi et al., 2001). All of the HVEM contacts are contained within the N-terminal loop of gD. (B) The crystal structure of gD bound to nectin-1 receptor (orange) is shown (PDB 3SKU) (Di Giovine et al., 2011). HVEM and nectin-1 bind to the same face of $\mathrm{gD}$. Nectin-1 binding prevents formation of the $\mathrm{gD} \mathrm{N}$ terminal loop, thus providing a structural basis for why HVEM and nectin-1 cannot bind to gD simultaneously. (C) The crystal structure of gD alone, not bound to receptor (PDB 1L2G) (Carfi et al., 2001). The nectin-1 contact residues (orange) and HVEM binding site (purple) are shown. The C-terminal region is not present in this structure. (D) The crystal structure of PRV gD alone (PDB 5X5V) (Li et al., 2017b), with nectin-1 contacts colored as in part C. The N-terminus of PRV gD is shorter than that of $\mathrm{HSV}-1 \mathrm{gD}$, providing a structural explanation for the failure of HVEM to serve as a PRV entry receptor. $(E)$. Surface rendering of HSV-1 gD alone from a mutant with a stabilized C-terminus (PDB 2C36) (Krummenacher et al., 2005). The C-terminus of the $\mathrm{gD}$ ectodomain was stabilized by the addition of a cysteine at residue 307 that resulted in a disulfidelinked $\mathrm{gD}$ dimer. The C-terminus of the gD ectodomain (residues 285-306, red) is shown, as well as the contact residues for HVEM (purple) and nectin-1 (orange). The position of the C-terminus occludes both the HVEM and nectin-1 binding sites, providing a structural basis for the increase in affinity for both HVEM and nectin-1 when this portion of the C-terminus is deleted from soluble forms of the gD ectodomain. (F). Surface rendering of HSV-1 gD from the gD-HVEM co-crystal (PDB 1JMA) (Carfi et al., 2001). The contact residues for HVEM (purple) and nectin-1 (orange) are shown. Binding of either receptor would require the C-terminus to move, as depicted by the red tail extending from gD. Movement of the C-terminus may serve as a signal for triggering the downstream fusion events. 
function mutations (not only in $\mathrm{gD}$, but also in $\mathrm{gB}$ ) that allow it to use other nectins for entry (nectins 2 through 4) (Cocchi et al., 2004b; Uchida et al., 2010).

The second class of $\mathrm{gD}$ receptors consists of the herpesvirus entry mediator (HVEM), a member of the tumor necrosis factor receptor superfamily, containing four characteristic cysteine-rich domains (CRD) (Carfi et al., 2001; Locksley et al., 2001). HVEM is used as a receptor by HSV-1 and HSV-2, but not by the other alphaherpesviruses including PRV, BHV-1, and herpes $B$ virus. HVEM is expressed primarily on lymphocytes, a cell type that is not a primary target for HSV infection (Montgomery et al., 1996; Raftery et al., 1999; Whitbeck et al., 1997). The affinity of HSV gD for HVEM is the same as it is for nectin-1 (Krummenacher et al., 1998; Willis et al., 1998). Interestingly, despite the fact that a single mutation in the HVEM binding site on $\mathrm{gD}$ can abrogate HVEM usage without preventing nectin-1 usage (Yoon et al., 2003), all of the 49 clinical isolates tested were able to use both HVEM and nectin-1 as a receptor (Krummenacher et al., 2004). This finding suggests a selective pressure to retain HVEM usage.

The third class of gD receptor, 3-O-sulfonated derivatives of heparan sulfate (3-OST HS), is generated by D-glucosaminyl-3-O-sulfotransferase-3 modification of heparan sulfate and can mediate the entry of HSV-1 (Shukla et al., 1999; Tiwari et al., 2007). 3-OST HS is present in neurons of the mouse trigeminal ganglion, but its contribution to HSV infection is yet unclear (Lawrence et al., 2007).

The relative importance of the receptors to HSV infection has been studied using mice knocked-out for one or two of the receptors. Intercranial infection of knock-out mice suggests that nectin-1 is required for infection and progression to encephalitis (Kopp et al., 2009). Intercranial infection in the absence of HVEM progressed as in wild-type mice, whereas mice lacking nectin-1 did not show disease. Similarly, when knock-out mice were infected intravaginally in the absence of nectin-1, the virus did not spread to the sensory ganglia, but 
infection in the absence of HVEM was normal (Taylor et al., 2007). Mice knocked-out for both HVEM and nectin-1 were resistant to infection of the vaginal epithelium, indicating that either receptor alone is sufficient for infection of epithelial cells. The role of HVEM in ocular infection is more complex. Corneal infection of the knockout mice revealed that the loss of either nectin-1 or HVEM attenuated HSV-1 infection of the cornea (Karaba et al., 2011), although infection with HSV-2 was not dependent on HVEM (Karaba et al., 2012). Further studies suggest that the contribution of HVEM to ocular disease is due to its immune modulatory role, rather than a direct role in virus entry (Edwards et al., 2015; Edwards and Longnecker, 2017).

\section{$g D$ and receptor structures}

The crystal structures of gD from HSV-1 (Carfi et al., 2001; Krummenacher et al., 2005), HSV-2 (Lee et al., 2013), and PRV (Li et al., 2017a) reveal a highly conserved domain organization (Figure $2 \mathrm{C}, \mathrm{D}$ ). The core of $\mathrm{gD}$ consists of a $\mathrm{V}$ like Ig fold flanked by long $\mathrm{N}$ - and $\mathrm{C}$-terminal extensions. Structures of $\mathrm{gD}$ cocrystallized with the receptors nectin-1 and HVEM have also been resolved, and $\mathrm{gD}$ binds to the membrane-distal $\mathrm{N}$-terminal regions of both receptors (Figure 2A, B) (Carfi et al., 2001; Di Giovine et al., 2011; Li et al., 2017a; Lu et al., 2014). The structure of HVEM is similar to that of other members of the tumor necrosis factor receptor family and is composed of four CRDs of approximately 40 residues each (Carfi et al., 2001). Although amino acids in both CRD1 and CRD2 of HVEM contact HSV gD, residue Y23 in CRD1 represents a "hot-spot" for gD binding while CRD2 is required mainly due to its effect on the presentation of the binding site on CRD1 (Carfi et al., 2001; Connolly et al., 2002; Whitbeck et al., 2001).

Nectin-1 and HVEM bind to HSV gD at distinct sites on the same face of $\mathrm{gD}$ (Carfi et al., 2001; Di Giovine et al., 2011; Krummenacher et al., 1998; Lu et al., 2014; Whitbeck et al., 1999). When HVEM is bound to gD, the gD N-terminus forms a hairpin loop and this loop comprises the entire HVEM-binding site (Figure 2A). Antibodies against a peptide corresponding to this $\mathrm{N}$-terminal gD loop neutralize viral infectivity (Cohen et al., 1984). The $\mathrm{N}$-terminal sequences 
of PRV and BHV-1 gD diverge from that of HSV-1 and HSV-2 gD, most likely because HSV gD uses this stretch for HVEM binding, whereas the others do not. In the absence of HVEM, the N-terminal gD residues do not form a hairpin and are disordered (Figure 2C) (Carfi et al., 2001). Therefore, the formation of the hairpin loop represents a conformational change in the $\mathrm{gD} \mathrm{N}$-terminus that must occur for HVEM to bind gD (Lazear et al., 2014). PRV gD contains a shortened N-terminal extension, as compared to HSV $\mathrm{gD}$, that is incapable of forming this hairpin (Figure 2D), coinciding with the inability of PRV gD to bind HVEM (Connolly et al., 2001). HVEM and nectin-1 cannot bind to gD simultaneously because the N-terminal hairpin loop formed via HVEM binding partially occludes the nectin-1 binding site (Figure 2A. B) (Di Giovine et al., 2011; Krummenacher et al., 2005). Comparison of the nectin-1 binding sites on HSV and PRV gD reveal a similar footprint on the core domain of gD (Figure $2 \mathrm{C}, \mathrm{D})$. The conservation of the nectin-1 binding site between HSV and PRV suggests that this binding site is conserved between most $\mathrm{gD}$ homologues.

3-OST HS has not been co-crystallized with $\mathrm{gD}$, however two sulfate ions found in the gD structure may represent the site of 3-OST HS binding, including one ion in a basic cavity on gD that is close to the gD/HVEM interface (Carfi et al., 2001). Further evidence that the 3-OST HS and HVEM binding sites on gD may overlap is that mutations in the $\mathrm{N}$-terminus of $\mathrm{gD}$ impact the usage of HVEM and 3-OST HS similarly (Yoon et al., 2003).

The C-terminal region of the $\mathrm{gD}$ ectodomain plays an important role in receptor binding and gD function. The structure of a dimeric form of HSV-1 gD, created by the addition of a disulfide bond at the end of the ectodomain, revealed that the $\mathrm{C}$-terminus of the $\mathrm{gD}$ ectodomain lies against the $\mathrm{gD}$ core, overlapping the nectin-1 binding site and occupying the same space as the gD N-terminal loop residues that form the HVEM binding site (Figure 2E) (Di Giovine et al., 2011; Krummenacher et al., 2005; Lu et al., 2014). The binding of either HVEM or nectin-1 would require the displacement of this C-terminus away from the $\mathrm{gD}$ core (Figure 2F). To validate the position of the $\mathrm{C}$-terminus in this structure, an additional gD mutant with a disulfide bond engineered to lock the $\mathrm{C}$-terminus 
against the gD core was crystallized (Krummenacher et al., 2005). As would be predicted, although this mutant was antigenically intact, it was unable to bind either receptor. Conversely, mutations in HSV and PRV gD that either delete the C-terminal tail or prevent its association with the $\mathrm{gD}$ core enhance binding to both nectin-1 and HVEM by 10-50 fold, due to an increase in the rate of complex formation $\left(k_{\text {on }}\right)$ (Krummenacher et al., 1999; Krummenacher et al., 2005; Rux et al., 1998; Willis et al., 1998) (Li et al., 2017a). Without the gD Cterminal tail bound to the $\mathrm{gD}$ core, the nectin-1 binding site is available for receptor binding and the $\mathrm{N}$-terminal hairpin loop can more readily form to permit HVEM binding. So, although the C-terminal tail of $\mathrm{gD}$ does not contain any receptor-contacting residues, this region influences gD-receptor binding.

\section{Transmitting a signal for fusion}

$\mathrm{gD}$ binding to receptor plays a greater role in virus entry than simply tethering the virus to the cell. gD homologs are not interchangeable, even when they bind the same nectin-1 receptor (Bohm et al., 2016; Fan et al., 2014). The Cterminus of $\mathrm{gD}$ appears to play a dual role in fusion by both inhibiting fusion when covering the receptor binding site and promoting fusion after receptor binding (Figure 1B). By creating a panel of gD mutants with engineered disulfide bonds that lock the C-terminus to the gD core at different points, a mutant was created that retained the ability to bind the receptors but failed to promote fusion (Lazear et al., 2008). This result suggests that the displacement of the C-terminus does more than just permit receptor binding. Moreover, an engineered gD mutant designed to force the displacement the Cterminal tail is able to mediate fusion at a low level in the absence of $\mathrm{gD}$ receptors (Gallagher et al., 2013), suggesting that displacement of this Cterminal tail is sufficient to trigger the downstream events required for fusion.

A region within the C-terminal tail (residues 261-285) of HSV gD has been termed the "profusion domain" due to its requirement for virus entry (Cocchi et al., 2004a; Zago et al., 2004). Since removal of the profusion domain inhibits virus entry without preventing gD-receptor binding, this region was proposed to serve as a binding site for $\mathrm{gHgL}$ and/or gB (Cocchi et al., 2004a; Gianni et al., 
2009). Indeed, antibodies that bind at the profusion domain inhibit cell-cell fusion and virus spread (Du et al., 2017; Lazear et al., 2012; Saw et al., 2015). However, the epitopes of several other anti-gD antibodies that neutralize virus without blocking $\mathrm{gD} /$ receptor binding map to regions outside the profusion domain (residues 54 and 67) (Atanasiu et al., 2018; Lazear et al., 2012). Both these neutralizing antibodies and those that bind to the profusion domain were shown to block the interaction between soluble $\mathrm{gD}$ and $\mathrm{gHgL}$ using surface plasmon resonance (SPR) (Cairns et al., 2019). The epitopes of these antibodies therefore outline a potential $\mathrm{gHgL}$ binding region on $\mathrm{gD}$ that spans a large region on the face adjacent to, but distinct from, the receptor binding site. In fact, both receptor (either HVEM or nectin-1) and gHgL were able to bind gD simultaneously (Cairns et al., 2019). It is currently unknown if, in the context of the virus, gD must disengage from receptor before its interaction with $\mathrm{gHgL}$ in order for the fusion cascade to proceed.

\section{Vaccine potential}

$\mathrm{gD}$ is a highly immunogenic protein and a prime target for vaccine development (Awasthi et al., 2014; Awasthi et al., 2015; Hook et al., 2018). Humans naturally infected with HSV-1, HSV-2, or both serotypes generate strong antibody responses against gD, that can be type-common or typespecific (Cairns et al., 2015; Cairns et al., 2014). In these individuals, the dominant immune response that results in virus-neutralizing antibodies is due to $\mathrm{gD}$ or a combination of $\mathrm{gD}$ and $\mathrm{gB}$. Anti-gD antibodies generated from natural infection correspond to three distinct $\mathrm{gD}$ epitopes, two involved in receptor binding and one involved in $\mathrm{gHgL}$ binding, and correlate with total antibody neutralization activity (Cairns et al., 2014).

\section{Retargeting HSV for oncolytic therapy}

Defining the receptor-binding sites on gD has stimulated attempts to detarget HSV from its natural receptors and retarget the virus to novel receptors. By inserting the appropriate natural ligands into the N-terminus of gD, HSV has been retargeted to use the interleukin-13 receptor or urokinase plasminogen activator receptor for entry, instead of nectin-1 or HVEM (Zhou and Roizman, 
2006, 2007; Zhou et al., 2002). HSV also has been retargeted to use human epidermal growth factor receptor 2 (HER2) and epidermal growth factor receptor (EGFR) for entry by mutating the native HVEM or nectin-1 binding sites in gD and inserting receptor-specific single-chain antibodies into gD (Menotti et al., 2008; Tuzmen et al., 2020; Uchida et al., 2010). Supplementing these $\mathrm{gD}$ mutations with additional manipulations in other glycoproteins that impact entry, including $\mathrm{gHgL}, \mathrm{gB}$, and $\mathrm{gK}$, may further strengthen the oncolytic potential for HSV (Campadelli-Fiume et al., 2016; Okubo et al., 2016; Petrovic et al., 2018). How the insertion of novel ligands into gD successfully recapitulates the triggering that normally occurs when wild-type gD binds a natural receptor is unclear.

\section{Glycoprotein $\mathrm{H}$ and glycoprotein L: Fusion regulators}

$\mathrm{gH}$ and $\mathrm{gL}$ form a heterodimer that is essential for both virus-cell and cell-cell fusion (Babic et al., 1996; Desai et al., 1988). This heterodimer is a target of antibodies that neutralize virus or inhibit cell-cell spread (Birlea et al., 2013; Buckmaster et al., 1984; Cairns et al., 2006; Gompels et al., 1991; Montalvo and Grose, 1986; Peng et al., 1998b; Rodriguez et al., 1993; Showalter et al., 1981; Xing et al., 2015). Although its requirement for herpesvirus entry has long been known, its precise role remains a mystery.

$\mathrm{gH}$ is a type I transmembrane protein, whereas $\mathrm{gL}$ is not membrane-anchored and, in alphaherpesviruses, associates non-covalently with the $\mathrm{gH}$ ectodomain. On mature virions and on the surface of HSV-infected cells, $\mathrm{gH}$ and $\mathrm{gL}$ are found together in a stable 1:1 complex (Peng et al., 1998a). gL expressed by itself is released into the media as a soluble protein (Dubin and Jiang, 1995; Hutchinson et al., 1992; Peng et al., 1998a). In contrast, for most alphaherpesviruses, $\mathrm{gH}$ expressed by itself is not transported to the cell surface and remains unfolded and trapped in the ER (Foa-Tomasi et al., 1991; Hutchinson et al., 1992; Klyachkin et al., 2006; Roberts et al., 1991). gH is able to be transported to the cell surface and incorporated into the virion only when co-expressed with gL (Dubin and Jiang, 1995; Hutchinson et al., 1992; Peng et al., 1998a; Roop et al., 1993; Wu et al., 2001). The exception to this rule is 
PRV $\mathrm{gH}$, which can be transported and incorporated into virions without $\mathrm{gL}$ (Klupp et al., 1997).

Although $\mathrm{gL}$ shares little amino acid identity across herpesviruses, $\mathrm{gH}$ is more conserved in sequence, and both are required for virus-cell and cell-cell fusion (Duus and Grose, 1996; Duus et al., 1995). Initially, gL was thought to be merely a chaperone or a scaffold protein for $\mathrm{gH}$. In fact, VZV gL contains a putative ER targeting signal at its $\mathrm{N}$ terminus instead of the typical signal sequence, a trait shared with ER chaperone proteins. Furthermore, when VZV $\mathrm{gH}$ was co-expressed with $\mathrm{gE}$ or $\mathrm{gl}, \mathrm{gH}$ was transported out of the $\mathrm{ER}$ and to the cell surface in the absence of $\mathrm{gL}$ (Duus et al., 1995). However, this $\mathrm{gH}$ was not processed completely and was most likely non-functional. Likewise, a mutant form of HSV-2 $\mathrm{gH}$ (with the $\mathrm{N}$-terminal 29 residues of the mature protein deleted) was transported to the cell surface in the absence of $\mathrm{gL}$ but was non-functional (Cairns et al., 2007). Co-expression with gL restored function to this $\mathrm{gH}$ mutant and these findings suggest that $\mathrm{gL}$ plays a role beyond the transport of $\mathrm{gH}$. In support of this concept, several HSV antibodies specific to $\mathrm{gL}$ have been isolated that inhibit cell-cell fusion and virus spread (Cairns et al., 2006; Novotny et al., 1996).

\section{$\mathrm{gHgL}$ is not a viral fusion protein}

Early on, $\mathrm{gHgL}$ was speculated to be a viral fusogen, i.e., an active participant in the mixing of virus and cellular membranes. Several labs identified potential fusion peptides within HSV-1 $\mathrm{gH}$ based on sequence analysis (Galdiero et al., 2005; Galdiero et al., 2007; Galdiero et al., 2006; Gianni et al., 2005a; Gianni et al., 2005b; Lopper and Compton, 2004). HSV-1 virions inactivated by neutralizing anti-gH antibodies or through the deletion of $\mathrm{gH}$ were reported to attach to cells and form a fusion bridge (Fuller and Lee, 1992). Although these viruses were unable to expand the bridge to allow entry, partial infectivity could be restored to $\mathrm{gH}$-null virions if a fusogenic agent was added to the cell medium (Babic et al., 1996; Forrester et al., 1992; Roop et al., 1993). In VZV, $\mathrm{gHgL}$ alone, produced from transfected cells, mediated low levels of cell-cell fusion (Duus et al., 1995). 
The proposed viral fusogen role for $\mathrm{gHgL}$ was refuted when the first structure of $\mathrm{gHgL}$ was determined (Chowdary et al., 2010). This structure of a soluble form of the HSV-2 $\mathrm{gH}$ ectodomain in complex with $\mathrm{gL}$ did not resemble any known fusogen. Although many helices within the core of $\mathrm{gH}$ formed helical bundles, the trimeric hairpin bundle characteristic of fusion proteins was absent from the $\mathrm{gHgL}$ structure. In fact, all of the previously hypothesized fusion peptides and heptad repeats were buried in the core of the protein and were unlikely to promote any significant conformational changes (Chowdary et al., 2010; Xing et al., 2015).

\section{gHgL structures}

The structure of HSV-2 $\mathrm{gHgL}$ revealed an extensive interaction between the two proteins that explained their interdependence for folding, transport, and function. gHgL has the overall shape of a "boot" (Figure 3A), which fits with earlier cryo-electron tomography studies of HSV-1 virions (Grunewald et al., 2003). $\mathrm{gH}$ itself is split into three domains: $\mathrm{H} 1$, which encompasses the $\mathrm{N}$ terminus and the gL-binding domain; $\mathrm{H} 2$, the helical central domain; and $\mathrm{H} 3$, the C-terminal $\beta$-sandwich "toe" of the boot and the domain closest to the transmembrane anchor (TM). The sequences of $\mathrm{gH}$ domain $\mathrm{H} 1$ and of $\mathrm{gL}$ vary substantially among herpesviruses, probably due to their co-evolution together as a tight-knit binding pair (Chowdary et al., 2010). The $\mathrm{N}$-terminal domain of $\mathrm{gH}$ lacks a folded core and requires $\mathrm{gL}$ for proper folding and stabilization.

The crystal structure of a soluble form of $\mathrm{VZV} \mathrm{gHgL}$ was also solved and bears a striking resemblance to that of HSV-2 (Figure 3B) (Xing et al., 2015). In addition, the structure of a core fragment of PRV $\mathrm{gH}$ (lacking $\mathrm{gL}$ and $\mathrm{H} 1$ ) was solved in complex with a FAb (Figure 3C) (Backovic et al., 2010; Vallbracht et al., 2019). Both the VZV and PRV structures adopt very similar folds to that of $\mathrm{HSV}-2$, especially in domains $\mathrm{H} 2$ and $\mathrm{H} 3$, which are the most highly conserved in their amino acid sequence. However, whereas HSV-2 and VZV gHgL are boot-shaped, the PRV $\mathrm{gH}$ C-terminal fragment adopts a more cylindrical shape, in which the $\mathrm{H} 2$ and $\mathrm{H} 3$ domains are aligned in the same plane. The 


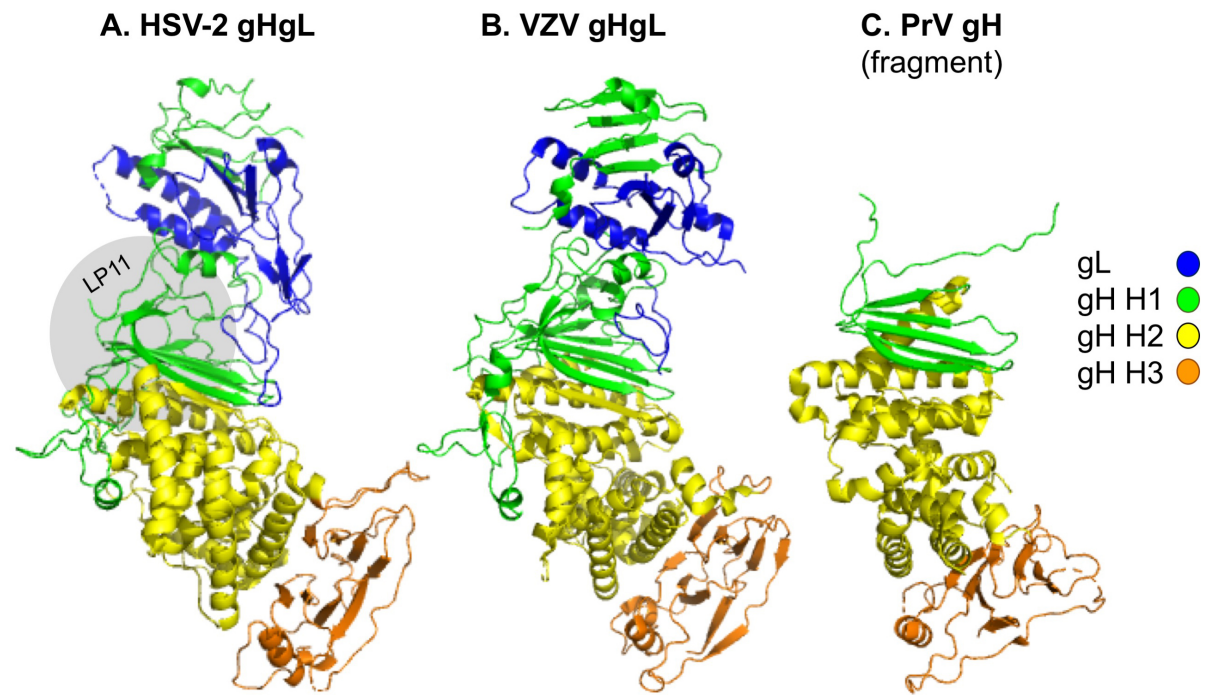

Figure 3. $\mathrm{gHgL}$ structures. (A) The crystal structure of the HSV-2 $\mathrm{gHgL}$ heterodimer (PDB 3M1C) (Chowdary et al., 2010). The structure is colored to define $\mathrm{gL}$ (blue) and three domains of $\mathrm{gH}$, including the gL-interacting domain $\mathrm{H} 1$ (green), the central helical domain $\mathrm{H} 2$ (yellow) and the $\mathrm{C}$-terminal $\beta$ sandwich domain $\mathrm{H} 3$ (orange). The $\mathrm{gH}$ domains are designated as originally defined in the $\mathrm{HSV}-2 \mathrm{gHgL}$ structure. The tight association of $\mathrm{gL}$ with the $\mathrm{N}$-terminal domain of $\mathrm{gH}$ provide a structural explanation for the requirement of $\mathrm{gL}$ for proper $\mathrm{gH}$ folding. The epitope for the neutralizing MAb LP11 (shaded gray) maps to domains $\mathrm{H} 1$ and $\mathrm{H} 2$, on the back of the heterodimer, and highlights a possible gB binding site. (B) The crystal structure of the VZV gHgL heterodimer (PDB 4XHJ) (Xing et al., 2015). The domains are colored as in part A. Both the HSV-2 and VZV structures adopt a boot shape. (C) The crystal structure of a fragment of PRV gH (PDB 2XQY) (Backovic et al., 2010). The domains are colored as in part A. The Nterminus of $\mathrm{gH}$ was absent from the protein crystallized and the core fragment of $\mathrm{gH}$ was co-crystallized with a Fab.

cylindrical shape of PRV $\mathrm{gH}$ more closely resembles that of the gammaherpesvirus EBV gHgL heterodimer (Matsuura et al., 2010). This difference in shape among alphaherpesvirus $\mathrm{gHgL}$ (boot vs. cylinder) may be due to the PRV structure lacking gL or being bound to a FAb or may it indicate that flexibility exists between the domains. 
The PRV $\mathrm{gH}$ structure highlighted the existence of an extended "flap" in domain $\mathrm{H} 3$, near where the ectodomain would transition to the TM of the protein and encounter the viral membrane (Backovic et al., 2010). This flap covers a conserved hydrophobic patch and the movement of this flap through isomerization of conserved disulfide bonds was hypothesized to expose the hydrophobic patch and allow it to interact with the lipid membrane (Backovic et al., 2010). In contrast, mutational analysis of this region in both PRV and VZV suggests that this "flap" needs to be rigid, not flexible (Fuchs et al., 2012; Vleck et al., 2011). Nevertheless, mutations in $\mathrm{gH}$ that abrogate or impair fusion typically map to domain H3 (Cairns et al., 2005; Galdiero et al., 1997; Jackson et al., 2010), highlighting its importance in membrane fusion and entry. This domain is also the most highly conserved, which implies a functional importance.

The $\mathrm{gH}$ TM and short cytoplasmic tail (CT) also contribute to gHgL function. Although a soluble form of the HSV $\mathrm{gHgL}$ ectodomain is able to trigger fusion of cells expressing $\mathrm{gB}, \mathrm{gD}$, and a $\mathrm{gD}$ receptor, the efficiency of fusion is lower, suggesting a role for the $\mathrm{gH}$ TM and/or CT in this process (Atanasiu et al., 2010a). Indeed, replacement or deletion of certain residues within the $\mathrm{gH}$ CT of HSV inhibit fusion (Browne et al., 1996; Jackson et al., 2010; Rogalin and Heldwein, 2015; Silverman and Heldwein, 2013; Wilson et al., 1994). gHgL anchored using a heterologous TM or a GPI-anchor is nonfunctional (Harman et al., 2002; Jones and Geraghty, 2004). In PRV, removal of the gH CT results in decreased membrane fusion activity, while deletion of the TM completely abolishes function (Vallbracht et al., 2018). Conversely, mutations in the VZV gH CT have been shown to enhance fusion (Yang et al., 2014).

\section{gHgL regulates viral fusion}

The crystal structure and the functional data indicate that $\mathrm{gHgL}$ is a fusion regulator. The core entry glycoproteins from HSV-1 and HSV-2 can be functionally swapped in the context of cell-cell fusion of receptor-bearing cells transfected with these four glycoproteins (Atanasiu et al., 2016; Muggeridge, 2000). These experiments demonstrate that the rate of cell-cell fusion is higher 
for HSV-2 than HSV-1 and that the gHgL serotype is a rate-limiting factor (Atanasiu et al., 2016). Similarly, several HSV-1 gH insertion mutants display a slow-fusing phenotype (Jackson et al., 2010). The current model proposes that, upon receiving a signal from $\mathrm{gD}$ after receptor binding, $\mathrm{gHgL}$ regulates the transition of the $\mathrm{gB}$ fusion protein from a prefusion to a fusion-activated state (Chowdary et al., 2010). HSV gHgL and gB interact only when gD and a gD receptor are also present (Atanasiu et al., 2007) (see below), suggesting that $\mathrm{gB}$ and $\mathrm{gHgL}$ are not normally associated and only come into contact when fusion is triggered. In addition, the $\mathrm{CT}$ of $\mathrm{HSV} \mathrm{gH}$ has been implicated in regulating fusion through an interaction with the $\mathrm{gB}$ cytodomain (Cooper et al., 2018; Rogalin and Heldwein, 2015). All current models of how gHgL regulates the fusogenic activity of $\mathrm{gB}$ involve a direct interaction between the three proteins, but capturing this multi-protein complex has proven challenging.

\section{$g \mathrm{HgL}$ as a receptor-binding protein}

In beta- and gammaherpesviruses, $\mathrm{gHgL}$, either alone or in complex with other viral proteins, binds to cellular receptors (Chen et al., 2018; Chen et al., 2019; Chesnokova and Hutt-Fletcher, 2011; Chesnokova et al., 2009; Hahn et al., 2012; Nishimura and Mori, 2019; Santoro et al., 2003; Wang and Shenk, 2005). Although most alphaherpesviruses use $\mathrm{gD}$ as a receptor binding protein, $\mathrm{gHgL}$ may bind its own cellular ligand(s) as well during entry. In VZV, which lacks $\mathrm{gD}$, cell-cell fusion mediated by $\mathrm{gB}$ and $\mathrm{gHgL}$ is reduced when av integrin expression is knocked down with siRNAs or when these integrins are bound by antibodies, suggesting an interaction between the viral glycoproteins and integrins (Yang et al., 2016). Interestingly, the canonical RGD motif and the disintegrin-like domain, both shown to bind integrins, are absent from VZV gB and $\mathrm{gHgL}$, suggesting that any potential interaction between integrins and the VZV core entry glycoproteins would occur through an as yet unidentified motif

Three different types of integrins have been shown to bind to HSV $\mathrm{gH}$ : avß3, av $\beta 6$, and av $\beta 8$ integrins (Gianni et al., 2013; Parry et al., 2005). av $\beta 3$ integrin binds HSV $\mathrm{gHgL}$ with low affinity and is proposed to serve as a "routing factor" because its silencing altered the route of virus infection but did not inhibit 
infection (Gianni and Campadelli-Fiume, 2012; Parry et al., 2005). Both av $\beta 6$ and $\alpha v \beta 8$ integrins bind $\mathrm{gHgL}$ with high affinity and contribute to the attachment of virus to the cell surface although they are less important for viral attachment than heparin sulfate (Gianni et al., 2013). Furthermore, the integrins could not substitute for the gD receptor nectin-1. $\alpha \vee \beta 6$ and $\alpha \vee \beta 8$ integrins have been proposed to act as additional HSV receptors that influence the pathway of HSV entry. The integrins may act as additional "triggers" for $\mathrm{gHgL}$, to determine when and where to signal $\mathrm{gB}$ to mediate fusion.

\section{Glycoprotein B: The viral fusogen}

Viral fusogens are proteins that execute the final membrane fusion step of viral entry by inserting into a target cell membrane and refolding to bring the viral and cell membranes together (White et al., 2008). Fusogens are initially present in a metastable prefusion conformation that, upon triggering, rearranges into an extended form that inserts hydrophobic residues into the target cell membrane. This extended conformation then refolds into a stable hairpin-like postfusion conformation to bring the membrane-inserted region into proximity with the membrane anchor of the protein, thereby facilitating fusion of the two membranes.

\section{Crystal structures of the $g B$ ectodomain}

$\mathrm{gB}$ is conserved in all herpesviruses and required for viral entry (Cooper and Heldwein, 2015). Crystal structures of the ectodomains of several gB homologs have been determined, including those from the alphaherpesviruses HSV-1 (Cooper et al., 2018; Heldwein et al., 2006) and PRV (Li et al., 2017b; Vallbracht et al., 2017), as well as from the betaherpesvirus cytomegalovirus (CMV) (Burke and Heldwein, 2015; Chandramouli et al., 2015) and the gammaherpesvirus Epstein-Barr virus (Backovic et al., 2009). These structures provide the strongest evidence that $\mathrm{gB}$ is a viral fusogen. $\mathrm{gB}$ shares structural similarity with the fusogens from rhabdoviruses (Baquero et al., 2015; Belot et al., 2020; Roche et al., 2006; Yang et al., 2020), baculovirus (Kadlec et al., 2008), and Thogotovirus (Peng et al., 2017) (Figure 4). This structural similarity is remarkable given a lack of sequence similarity among these viral fusogens. 


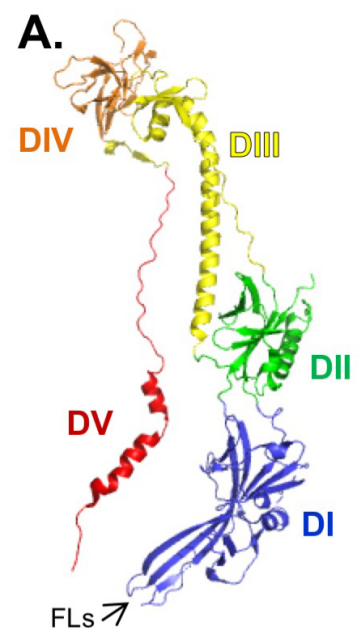

HSV gB
B.

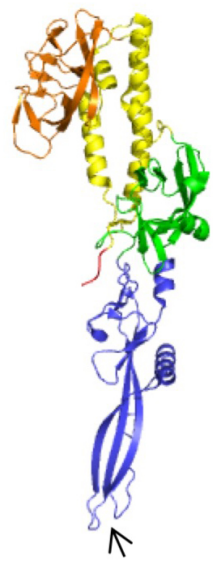

VSV G
C.

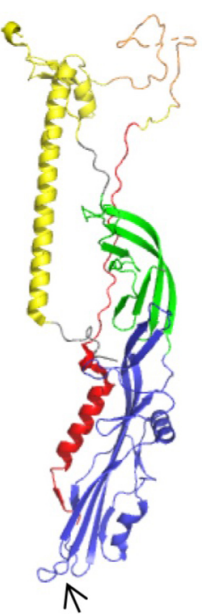

AcMNPV Gp64
D.

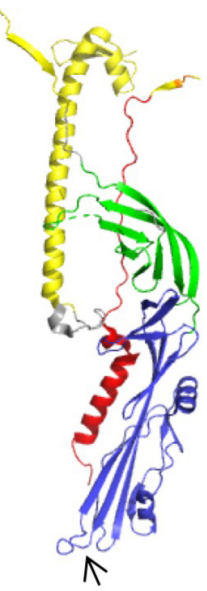

THOV Gp

Figure 4. Class III fusogens. (A) The crystal structure of the HSV-1 gB monomeric ectodomain is shown (PDB 2GUM) with each structural domain (DI-DV) colored (Heldwein et al., 2006). The location of the fusion loops (FLs) is indicated with an arrow. The crystal structures of rhabdovirus VSV G (B) (PDB 512M) (Roche et al., 2006), baculovirus Autographa californica nucleopolyhedrovirus Gp64 (C) (PDB 3DUZ) (Kadlec et al., 2008), and Thogotovirus Gp (D) (PDB 5XEA) (Peng et al., 2017) monomeric ectodomains are shown in ribbon diagram, with domains colored as in part A. The VSV G structure is missing domain V, while domain IV was unresolved in Thogotovirus Gp. All four fusion proteins are positioned with their fusion loops pointing down (arrows).

Together, these proteins represent class III of fusogens (Backovic and Jardetzky, 2009). Structures of both the prefusion and postfusion forms of the rhabdovirus fusion protein $G$ from vesicular stomatitis virus (VSV) and rabies virus have been determined, an accomplishment facilitated by the ability of $G$ to undergo reversible, pH-dependent conformational changes (Roche et al., 2007; Yang et al., 2020). Structural similarity to $G$ indicates that the gB crystal structures represent the postfusion conformation.

$\mathrm{gB}$ is a trimeric type I transmembrane protein, with a large ectodomain, a single transmembrane domain (TM), and a cytoplasmic tail domain (CT). The $\mathrm{gB}$ ectodomain is organized into five domains (Figure 5A) (Heldwein et al., 

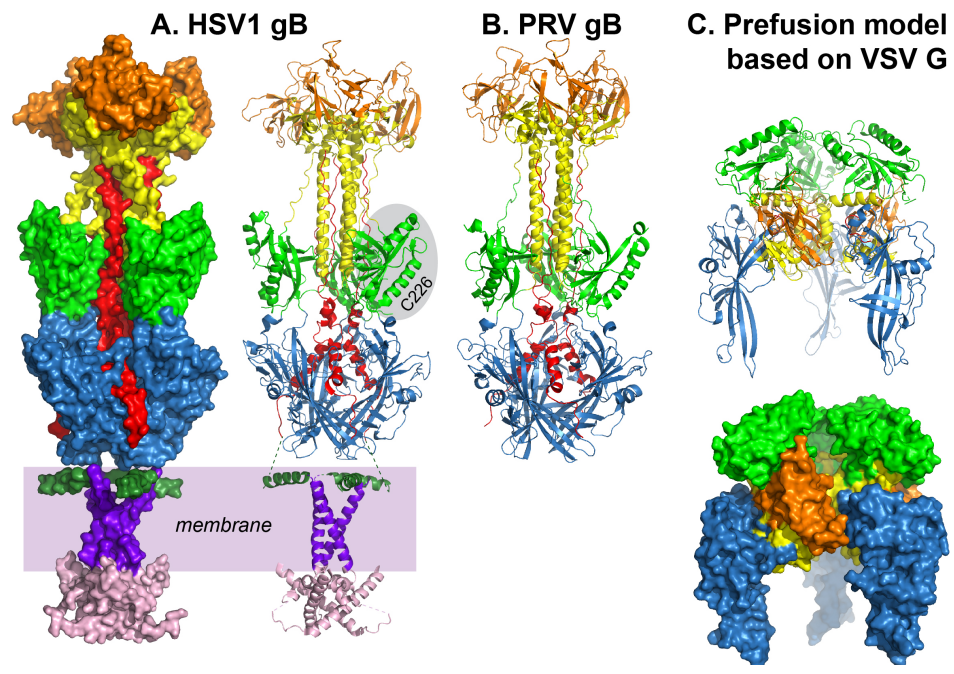

D. Alternate form based on cryoET

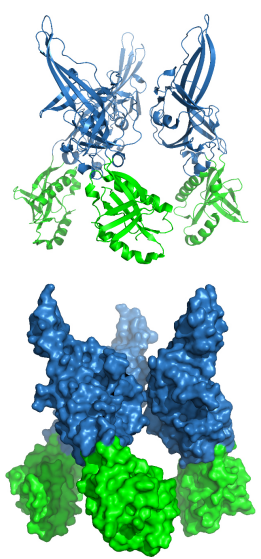

Figure 5. gB structures. (A) The crystal structure of full-length HSV-1 gB is shown, with surface rendering on the left and a ribbon diagram on the right (PDB 5V2S) (Cooper et al., 2018). This structure represents the postfusion conformation and the presumed position of the membrane is indicated by a purple box. Five domains of the ectodomain are colored, including domains I (blue), II (light green), III (yellow), IV (orange), and V (red). C-terminal to the ectodomain, the membrane-proximal region (MPR, dark green), a single-pass transmembrane domain (TM, purple) and cytoplasmic domain (CT, pink) are shown. The fusion loops are located at the tip of domain I, in contact with the membrane. Domain V extends the length of the molecule and packs against the central coiled-coil of domain III before descending into the MPR. The MPR lies parallel to the membrane and the single-pass TM forms an inverted teepee beneath the structure. The CT has trimeric contacts that may influence the activation of $\mathrm{gB}$. The epitope for the neutralizing MAb C226 (shaded gray) maps to domain II (Atanasiu et al., 2010b) and highlights a possible binding site for $\mathrm{gHgL}$. (B) The crystal structure of PRV $\mathrm{gB}$ ectodomain is shown in ribbon diagram, with domains colored as in part A (PDB 6ESC) (Vallbracht et al., 2017). The structural similarity between HSV-1 and PRV $\mathrm{gB}$ is apparent. (C) A working model of prefusion HSV-1 $\mathrm{gB}$ is shown, as a ribbon diagram at the top and surface rendering at the bottom (Gallagher et al., 2014). This model was generated by fitting the domains from the postfusion gB structure to the prefusion crystal structure of VSV G (PBD 2J6J) (Roche et al., 2007). The model presumes that the gB prefusion-to-postfusion conformational change is comprised primarily of tertiary structure rearrangements. The model predicts a break in the extended coil of domain III and domain V is absent because it is not present in the VSV G structure. (D) A model of an alternative conformation of $\mathrm{gB}$, based on cryoET, is shown (Zeev-Ben-Mordehai et al., 2016). Fitting domains I and II from the postfusion $\mathrm{gB}$ structure into this form orients the fusion loops away from the membrane. Domains III-V from the postfusion structure were not placed into this form and the structure would not accommodate the intact extended coil of domain III. 
2006). Domain I, the "fusion domain", is located at the base of the ectodomain, near the membrane. This domain contains a pleckstrin-homology domain along with two adjacent beta-hairpin extensions that present hydrophobic residues at their tips that can insert into membranes ("fusion loops") (Falanga et al., 2012). Mutational studies demonstrate that the hydrophobic residues in the fusion loops are essential for the gB fusogenic function (Backovic et al., 2007; Hannah et al., 2009; Oliver et al., 2009; Vallbracht et al., 2017). Structural domain II contains a second pleckstrin-homology domain.

The core of gB consists of a long central helix (domain III). In the gB trimer, three helices twist around one another to form an extended coiled-coil (Figure $5 A)$. An extended polypeptide in domain $V$ spans the length of the molecule and packs against the coiled-coil. Domain $\mathrm{V}$ from one protomer packs against domain III of two other protomers in an anti-parallel orientation. The packing of domain $\vee$ against the central coil is analogous to a six-helix bundle, a structural feature that is present in the postfusion form of class I fusogens. Formation of this very stable, low-energy structure has been proposed to contribute energy for membrane fusion (Melikyan et al., 2000). Mutations that are predicted to disrupt the interaction between domains III and V reduce both the rate of viral entry and the extent of cell-cell fusion (Connolly and Longnecker, 2012; Fan et al., 2017). In addition, peptides that include sequences from domain III or $\mathrm{V}$ have been shown to inhibit viral entry (Akkarawongsa et al., 2009), supporting the notion that these regions are exposed at some point during conformational rearrangements and come together as $\mathrm{gB}$ folds into its final postfusion conformation.

The $C$ terminus of domain $V$ threads through domain I (Figure $5 A$ ). In the fulllength protein, domain $\mathrm{V}$ would then lead into the membrane proximal region (MPR), TM and CT. The close juxtaposition of the $C$ terminus of domain $V$ and the fusion loops of domain I in the postfusion form of $\mathrm{gB}$ explains how folding to the postfusion form could bring the two membrane-anchored portions of the protein into proximity, similarly to the postfusion forms of fusogens from other classes (Harrison, 2015). 


\section{Transmembrane and cytoplasmic domains of $g B$}

For gB crystallization, removal of the MPR, TM, and CT to create a soluble ectodomain presumably resulted in spontaneous folding into a postfusion form. The TM and/or CT appear to be critical for maintaining the prefusion form of $\mathrm{gB}$, as has been observed for some class I fusogens (Yin et al., 2005; Yin et al., 2006). This postfusion gB structure is remarkably stable. Mutants designed to capture an alternate conformation of $\mathrm{gB}$, by substituting the $\mathrm{TM}$ with a trimeric domain or by adding mutations known to prevent fusion, still adopt the postfusion form (Silverman et al., 2010; Vitu et al., 2013).

The crystal structure of the full-length gB, including the MPR, TM, and CT, was determined recently (Figure 5A, B) (Cooper et al., 2018). The ectodomain of this full-length molecule adopted a postfusion conformation, likely due to detergent solubilization. The MPR lies beneath the ectodomain, parallel to the membrane, the TM forms an inverted teepee, and the CT forms a trimeric pedestal. The gB CT is significantly longer than the CT of other class III fusogens, and mutational studies indicate that it plays a crucial role in fusion. Some mutations in the CT inhibit fusion (Cai et al., 1988; Wanas et al., 1999) whereas others can enhance fusion and/or impart a syncytial phenotype (Baghian et al., 1993; Diakidi-Kosta et al., 2003; Engel et al., 1993; Fan et al., 2002; Foster et al., 2001; Gage et al., 1993; Heineman and Hall, 2002; Muggeridge et al., 2004; Oliver et al., 2013; Silverman et al., 2012). Mapping known $\mathrm{gB}$ mutations to this $\mathrm{gB} C \mathrm{CT}$ structure suggests that this structure is present in the prefusion form of the protein. The structural and mutagenic data together suggest that the $\mathrm{CT}$ stabilizes the prefusion form of $\mathrm{gB}$, interacting with the membrane and acting as a clamp to control the refolding of the protein. The CTs of other fusion proteins impart a similar regulation of fusion function (Waning et al., 2004; Wyss et al., 2005).

\section{Alternate conformations of the $g B$ ectodomain}

For gB, only the structure of the postfusion form is known. Computational homology models of the prefusion $\mathrm{gB}$ have been generated using the prefusion 
structure of VSV G (Figure 5C) (Backovic et al., 2009; Gallagher et al., 2014). These models predict that the extended helix of the domain III core is partially unfolded in the prefusion form while domain $\mathrm{V}$ could not be modeled because it is absent from the VSV G structure.

Recently, cryo-electron tomography (cryoET) reconstructions of membraneanchored HSV-1 gB by two research groups have revealed alternative compact forms of gB with trimeric symmetry (Fontana et al., 2017; Zeev-Ben-Mordehai et al., 2016). In the first study, gB was visualized on the surface of extracellular vesicles produced in cells overexpressing HSV-1 gB (Zeev-Ben-Mordehai et al., 2016). Two distinct conformations of gB were detected, one that matched the known postfusion form and the other, a more compact, novel trimeric form, which could represent prefusion gB or an intermediate form between pre- and postfusion. Fitting domains I and II from the postfusion $\mathrm{gB}$ structure into the compact form positioned domain I distal to the membrane, with the fusion loops facing away from the membrane (Figure 5D). Interestingly, this fitting resulted in the distances between the fusion loops of each $\mathrm{gB}$ protomer being similar to the distances between fusion loops in the prefusion VSV G. Domains III-V did not fit into the model, potentially due to structural rearrangements in those domains.

The second cryoET study used landmarks to orient gB during imaging of fulllength $\mathrm{gB}$ on vesicles, including large insertions of fluorescence proteins at known sites in $\mathrm{gB}$ and antibodies with known binding sites on $\mathrm{gB}$ (Fontana et al., 2017). Proper folding of $\mathrm{gB}$ on these vesicles was confirmed using a panel of antibodies specific for conformational epitopes, suggesting that this $\mathrm{gB}$ is in the prefusion conformation. Using these landmarks, the computational model of HSV gB based on prefusion VSV G (Gallagher et al., 2014) was fit into the structure with the fusion loops oriented towards the membrane (Figure $5 \mathrm{C}$ ). A recent cryoET study of CMV gB also oriented the fusion loops towards the membrane ( $\mathrm{Si}$ et al., 2018). Although these cryoET studies propose different orientations of $\mathrm{gB}$ with respect to the membrane, the studies all reveal alternate membrane-anchored forms of $\mathrm{gB}$ that, at heights of $8-10 \mathrm{~nm}$, are 
significantly shorter than the 16-18-nm postfusion form. Both models also predict extensive conformational changes in domains III and $\mathrm{V}$ during the transition from a prefusion to the postfusion conformation.

While comparisons to the prefusion VSV G structure provide a valuable working model for the prefusion $\mathrm{gB}$ structure, the prefusion form of gB likely differs from that of VSV G. Alphaherpesvirus entry can occur at neutral $\mathrm{pH}$ and requires triggering by other entry glycoproteins, whereas triggering of conformational changes in VSV G is pH-dependent, reversible, and does not require other viral glycoproteins (Ferlin et al., 2014; Roche et al., 2008). Interestingly, exposure to low $\mathrm{pH}$ has been shown to cause antigenic changes in HSV-1 and HSV-2 gB, some of which are reversible (Cairns et al., 2011; Dollery et al., 2010a; Dollery et al., 2011; Muggeridge, 2012; Nicola, 2016; Siekavizza-Robles et al., 2010; Weed et al., 2018). Ultimately, a detailed understanding of the prefusion form of $\mathrm{gB}$, including the organization of domains III and V, will require determination of the structure at atomic resolution.

\section{Functional regions across $g B$}

HSV gB elicits neutralizing antibodies (Cairns et al., 2015; Cairns et al., 2014), but all of the antibodies that have been tested can bind to the postfusion conformation (Bender et al., 2007), suggesting that these MAbs do not inhibit fusion by trapping a prefusion conformation. Neutralizing MAbs map to different domains within the $\mathrm{gB}$ ectodomain, indicating that multiple regions of $\mathrm{gB}$ are critical for proper refolding during fusion and/or interactions with other glycoproteins. Likewise, insertion mutations in each of the gB domains can prevent fusion function (Lin and Spear, 2007). By mapping the epitopes for the neutralizing antibodies, four distinct functional regions (FR) on the surface of HSV gB were defined (Bender et al., 2007). FR1 lies at the base of the postfusion structure and includes the fusion loops and regions of both domain I and V. FR2 maps to domain II and may overlap a gHgL interaction site (see below). FR3 is located on the gB crown and includes regions of domain III and IV. Finally, FR4 maps to the $\mathrm{N}$-terminal region of $\mathrm{gB}$ that was not resolved in 
the structure and includes the binding site for heparan sulfate proteoglycan (HSPG) (Laquerre et al., 1998).

\section{Receptors for $g B$}

In addition to its role as the fusogen, HSV gB binds several host surface molecules. While gB can bind to HSPG, this interaction is not essential for virus entry. HSV gB can also bind to paired immunoglobulin-like type 2 receptor- $\alpha$ (PILRa), an immune regulator (Fan et al., 2009; Satoh et al., 2008; Wang et al., 2009). PILRa is not required for HSV entry into all cells; however, its expression in the absence of $\mathrm{gD}$ receptors can mediate virus entry into cells and low levels of cell-cell fusion. Interestingly, gD must be present for PILRamediated fusion to occur. The clinical importance of PILRa has yet to be determined; however, it may contribute to entry into retinal pigment epithelial cells (Shukla et al., 2009) and replication on murine cornea (Arii et al., 2010b). Two additional gB receptors that enhance HSV entry have been described, including myelin-associated glycoprotein (MAG) (Suenaga et al., 2010) and myosin-9 (also called non-muscle myosin heavy chain IIA, NMMHC-IIA) (Arii et al., 2010a). MAG also binds to VZV gB and can enhance VZV entry into cells (Suenaga et al., 2010), although it is not required for infection. The ability of receptors to trigger fusion by binding to $\mathrm{gB}$ diverges from the current model of entry, in which a signal for fusion is transmitted to $\mathrm{gB}$ by $\mathrm{gHgL}$. Future structural studies of $\mathrm{gB}$ complexed with these receptors may reveal a mechanism of activation.

\section{Viral accessory proteins for $g B$}

Although transfection of gD-receptor-bearing cells with the core HSV entry glycoproteins $\mathrm{gD}, \mathrm{gH}, \mathrm{gL}$, and $\mathrm{gB}$ is sufficient for cell-cell fusion, other virally encoded proteins influence fusion in the context of the viral entry. For example, while certain mutations in the gB CT impart a syncytial (syn) phenotype (Cooper et al., 2018; Gage et al., 1993; Silverman et al., 2012), syn mutations also map to other viral genes, including gK, UL20, and UL24 (Dolter et al., 1994; Leiva-Torres et al., 2010). gK and UL20 interact both with gB and with each other (Chouljenko et al., 2010). Although gK is not required for cell-cell 
fusion, deletion of the $\mathrm{N}$ terminus of $\mathrm{gK}$ inhibits entry into neurons in culture and spread to the mouse trigeminal ganglia after ocular infection (Jambunathan et al., 2015; Musarrat et al., 2018). Additional viral proteins also contribute to fusion in potentially complex ways. For example, UL21 is required for the syncytial phenotype of gB syn mutants, but not gK, UL20, or UL24 syn mutants (Sarfo et al., 2017). Other proteins that also have been reported to influence fusion include gE, gl, gM, gN, UL11, UL16, and UL45 (Dollery et al., 2010b; El Kasmi and Lippe, 2015; Haanes et al., 1994; Han et al., 2012; Kim et al., 2013).

\section{Interactions among entry glycoproteins}

\section{Detecting interactions}

HSV entry glycoproteins can be chemically crosslinked, indicating their proximity on the viral envelope (Handler et al., 1996); however, formation of a stable entry complex prior to entry is unlikely because individual glycoprotein deletions do not disrupt glycoprotein incorporation into the virion (Rodger et al., 2001). HSV gD is reported to co-immunoprecipitate (colP) with both $\mathrm{gHgL}$ and gB (Gianni et al., 2009), and, in one study, the colP of gD with $\mathrm{gHgL}$ was dependent on the presence of receptor (Perez-Romero et al., 2005). A direct association of purified soluble forms of $\mathrm{gHgL}$ and $\mathrm{gB}$ in the presence of liposomes has be detected at low pH (Cairns et al., 2011). Lateral interactions among $\mathrm{gB}$ trimers also have been observed by $\mathrm{EM}$ of soluble $\mathrm{gB}$ bound to liposomes (Maurer et al., 2013).

Direct interactions among the essential HSV entry glycoproteins have also been examined using bimolecular fluorescence complementation (BiFC), a technique in which two inactive halves of a fluorescent protein, for example, green fluorescent protein (GFP), are fused onto separate glycoproteins. Interaction between the glycoproteins brings the two halves into proximity such that the active fluorescent protein forms. Using BiFC, interactions between all of the essential HSV entry glycoproteins ( $\mathrm{gD} / \mathrm{gB}, \mathrm{gD} / \mathrm{gHgL}, \mathrm{gHgL} / \mathrm{gB}$ ) have been detected in two independent studies (Atanasiu et al., 2007; Avitabile et al., 2007). In one study, the interaction of $\mathrm{gHgL}$ with $\mathrm{gB}$ was dependent on the 
presence of both $\mathrm{gD}$ and its receptor, suggesting a cascade of interactions starting with $\mathrm{gD} /$ receptor and ending with $\mathrm{gHgL} / \mathrm{gB}$ (Atanasiu et al., 2007). Interestingly, although each BiFC construct was functional individually, coexpression of complementary $\mathrm{gD}$ and $\mathrm{gH}$ BiFC constructs inhibited fusion, suggesting that the $\mathrm{gD} / \mathrm{gHgL}$ interaction may need to be transient. This was further supported by recent SPR experiments showing that $\mathrm{gH} / \mathrm{gL}$ binds to $\mathrm{gD}$ rapidly and also rapidly dissociates from it (Cairns et al., 2019).

\section{Mapping interactions}

Putative interaction sites on the glycoproteins can be mapped by blocking their interactions with neutralizing antibodies that bind to defined epitopes. Using SPR, MAbs that block gD-gHgL binding were used to map the $\mathrm{gHgL}$ binding site on gD to a large region adjacent to, but separate from, the receptor binding domain (Cairns et al., 2019). Using BiFC, the gHgL interaction site on gB was mapped to gB domain II, overlapping the epitope for the MAb C226 in FR2 (Figure 5) (Atanasiu et al., 2010b). Similarly, the gB interaction site on $\mathrm{gHgL}$ was mapped to a conserved groove in domains $\mathrm{H} 1 / \mathrm{H} 2$ of $\mathrm{gHgL}$, overlapping the epitope for the MAb LP11 (Figure 3) (Chowdary et al., 2010).

Interaction sites on glycoproteins can also be mapped by creating chimeric entry glycoproteins that carry regions from non-complementing viral species. By coexpressing various combinations of HSV-1 and saimiriine herpesvirus 1 (SaHV-1) entry glycoproteins, a species-specific functional interaction between $\mathrm{gD}$ and $\mathrm{gHgL}$ was demonstrated (Fan et al., 2014). By generating gHgL chimeras encoding segments of HSV-1 and SaHV-1 sequence, a gD interaction site within $\mathrm{gHgL}$ was mapped to domains $\mathrm{H} 1$ and the $\mathrm{N}$ terminus of $\mathrm{H} 2$, in the membrane-distal region of the $\mathrm{gH}$ ectodomain (Fan et al., 2015). Consistent with a model that $\mathrm{gD}$ interacts with the $\mathrm{N}$ terminus of $\mathrm{gHgL}$, an $\mathrm{N}$ terminally truncated form of $\mathrm{HSV}$ gHgL can mediate gD-independent cell-cell fusion (Atanasiu et al., 2013). Taken together, these studies suggest gD may trigger a conformational change in the $\mathrm{N}$-terminus of $\mathrm{gHgL}$. 
Species-specific interactions also have been used to map $\mathrm{gHgL}-\mathrm{gB}$ interactions. Chimeric constructs combining $\mathrm{gHgL}$ sequences from HSV-1 and PRV were used to map a species-specific gHgL-gB interaction site to domain $\mathrm{H} 3$ at the $\mathrm{C}$ terminus of the $\mathrm{gHgL}$ ectodomain (Bohm et al., 2016). Interestingly, these chimeric $\mathrm{gHgL}$ studies and the BiFC approach identified distinct sites on $\mathrm{gHgL}$ that contribute to the $\mathrm{gB}$ interaction, in domains $H 3$ and $H 1 / H 2$, respectively. A potential explanation for this discrepancy is that, in the BiFC studies, MAb binding to $\mathrm{H} 1 / \mathrm{H} 2$ may alter the presentation of an interaction site in H3. Conversely, in the chimera studies, domain H3 may influence the presentation of an interaction site in $\mathrm{H} 1 / \mathrm{H} 2$.

Defining interactions among the herpesvirus glycoproteins has been challenging, likely due to low-affinity or transient interactions. Using chimeric constructs to map functional interaction sites may reveal domains of a protein that are required for an interaction, but this approach does not exclude the possibility that other regions of the protein also contribute to the interaction. Using neutralizing antibodies to map interactions is complicated by the fact that antibody binding may alter the protein structure and/or block an interaction by steric hindrance. Neither approach can identify the specific residues that mediate glycoprotein interactions. Accurate mapping of HSV glycoprotein interaction sites awaits future studies, in which structures of entry complexes determined by cryoET or $x$-ray crystallography can be verified using biochemical assays.

\section{Routes of entry}

Due, in part, to compelling electron micrographs showing alphaherpesvirus particles fusing directly with the plasma membrane (Granzow et al., 1997), the entry of alphaherpesviruses for a long time was thought to occur at the plasma membrane at a neutral $\mathrm{pH}$. Upon subsequent reassessment, the route of entry into cells for alphaherpesviruses was shown to be dependent on cell type, as for beta- and gammaherpesviruses (Compton et al., 1992; Hutt-Fletcher, 2007; Ryckman et al., 2006). For example, HSV enters keratinocytes, human epithelial HeLa cells, and Chinese hamster ovary $(\mathrm{CHO})$ cells in a $\mathrm{pH}$ - 
dependent manner via endocytosis (Nicola et al., 2005; Nicola et al., 2003; Nicola and Straus, 2004), whereas HSV fuses directly with the plasma membrane during entry into neurons, keratinocytes, human epithelial Hep2 cells, and Vero cells (Fuller and Spear, 1987; Koyama and Uchida, 1987; Nicola et al., 2005; Rahn et al., 2011; Sodeik et al., 1997; Wittels and Spear, 1991). Similarly, equine herpesvirus (EHV) enters $\mathrm{CHO}$ cells and endothelial cells via endocytosis but enters rabbit kidney RK13 cells by fusion at the plasma membrane (Frampton et al., 2007; Hasebe et al., 2009; Van de Walle et al., 2008).

Why endocytosis is required for entry into some cells but not into others is unknown. For entry via endocytosis, the low $\mathrm{pH}$ environment of the endosome appears to serve as a trigger for fusion, since agents that disrupt endosomal pH prevent entry (Nicola et al., 2005; Nicola et al., 2003). Low pH can affect gB conformation and oligomeric state, in both reversible and irreversible manners (Cairns et al., 2011; Dollery et al., 2010a; Dollery et al., 2011; Muggeridge, 2012; Weed et al., 2018). Interestingly, there is evidence that gC may selectively facilitate low-pH entry by regulating conformational changes in $\mathrm{gB}$ (Komala Sari et al., 2020). VSV G, another class III fusion protein, also undergoes reversible $\mathrm{pH}$-triggered conformational changes (Roche et al., 2007), raising the question of whether gB is triggered similarly to VSV G. Nevertheless, endocytosis appears to contribute more to entry than simply an exposure to low $\mathrm{pH}$, because exposure of HSV to acidic $\mathrm{pH}$ fails to trigger the fusion of bound virus with the plasma membrane (Walker et al., 2015). In addition, in some cases, HSV-1 can enter cells via endocytosis without a low $\mathrm{pH}$ requirement (Milne et al., 2005).

\section{Discussion}

Recent work, driven in large part by structural studies of the core entry machinery, has improved our understanding of the stepwise mechanism for alphaherpesvirus entry into cells (Figure 1B). The identification of entry receptors has shown that nectin-1 serves as a common receptor that is critical for infection. The biological relevance of the receptors that bind to $\mathrm{gB}$, the HSV 
receptor HVEM, and the potential entry receptors for VZV (Chen et al., 2004; Suenaga et al., 2015; Suenaga et al., 2010; Yang et al., 2016) is yet unclear. The comparison of several $\mathrm{gD}$ structures indicates that the $\mathrm{C}$ terminus of the gD ectodomain shifts upon receptor binding. Future studies will determine how this shift exposes a $\mathrm{gHgL}$ interaction site as well as map the precise location of this site, be it within the $\mathrm{gD} C$ terminus or within the $\mathrm{gD}$ core.

$\mathrm{gHgL}$ structures from three different alphaherpesviruses indicated that this essential entry glycoprotein complex is not a viral fusogen and allowed the design of structure-based experiments to dissect its function and sites of interaction. How the $\mathrm{gHgL}$ conveys a fusion signal from $\mathrm{gD}$ (and/or receptor) to $\mathrm{gB}$ has not yet been determined. $\mathrm{gHgL}$ could, potentially, adopt multiple conformations, including a native, pre-triggered conformation, a gD-activated conformation, and a post-triggered conformation.

To date, all of the gB variants isolated for crystallographic studies, including those containing intact TM and CT, adopted the postfusion conformation (Cooper et al., 2018; Vitu et al., 2013). CryoET of membrane-associated gB reveals compact forms of $\mathrm{gB}$ with trimeric symmetry that may represent a prefusion or an alternative conformation (Fontana et al., 2017; Zeev-BenMordehai et al., 2016). These compact structures cannot accommodate the extended coil of domain III, seen in the postfusion form, indicating that $\mathrm{gB}$ undergoes extensive conformational rearrangement to mediate membrane fusion. Structural and mutagenic data suggest that the gB CT acts as a clamp, regulating $\mathrm{gB}$ activation.

\section{Future trends}

Despite recent advances, many questions regarding the entry of alphaherpesviruses remain. Structural approaches, including both crystallography and cryoET, will continue to prove indispensable for addressing the remaining questions in alphaherpesvirus entry. CryoET in particular is being employed more frequently to examine the structures of individual proteins. Results from these structural studies will provide the basis for 
hypotheses that can be tested using mutagenesis and functional assays of entry and membrane fusion.

What do the complexes of $\mathrm{gD} / \mathrm{gHgL}$ and $\mathrm{gHgL} / \mathrm{gB}$ look like? What surfaces of the proteins serve as contact sites? Stable association of these complexes will be required for structural studies, a notable disadvantage for the alphaherpesviruses compared to other herpesviruses (Ciferri et al., 2015; Sathiyamoorthy et al., 2016). Identification of antibodies and/or mutations that stabilize potentially transient conformations of these proteins may facilitate structural studies of the complexes.

Why is $\mathrm{gHgL}$ required for the entry of herpesviruses? Viruses from most other families use a single protein to mediate both receptor-binding and membrane fusion. Paramyxoviruses encode separate receptor-binding and fusion proteins; however, they do not require an additional protein to serve as a "bridge" between the receptor-binding protein and fusion protein. How exactly does $\mathrm{gHgL}$ trigger $\mathrm{gB}$ ? Although a purified form of the $\mathrm{gHgL}$ ectodomain can trigger fusion at low levels (Atanasiu et al., 2010a), mutational studies indicate that the $\mathrm{gH}$ TM and short CT domains are critical for function (Browne et al., 1996; Harman et al., 2002; Wilson et al., 1994). Do interactions between the gH CT and gB CT influence gB triggering (Cooper et al., 2018; Rogalin and Heldwein, 2015; Silverman and Heldwein, 2013)? In addition, does gHgL have any direct impact on the cellular or viral membranes at the site of fusion? What additional roles does $\mathrm{gHgL}$ play during VZV entry?

What conformational changes are required for and/or triggered by complex formation among the entry glycoproteins? Does $\mathrm{gHgL}$ adopt multiple distinct conformations as it interacts with $\mathrm{gD}$ and $\mathrm{gB}$ ? What does the prefusion form of gB look like and where are the fusion peptides positioned in this form? What intermediate conformation(s) does $\mathrm{gB}$ fold into as it transitions from its prefusion to postfusion form? Can an extended form of gB, embedded in both the cellular and viral membranes, be captured? Defining the conformational changes required for entry may highlight regions susceptible to inhibition by 
small molecules, offering tools to trap intermediate conformations for further study and potentially providing a basis for the development of antiviral drugs that inhibit virus entry.

\section{Web resources}

Structures of the alphaherpesvirus entry glycoproteins can be accessed from the protein data bank (https://www.rcsb.org). These crystal structures include unliganded HSV-1 gD (1L2G, 2C3A, and 2C36) (Carfi et al., 2001; Krummenacher et al., 2005), HSV-1 gD bound to HVEM (1JMA) (Carfi et al., 2001), HSV-1 gD bound to nectin-1 (3SKU and 3U82) (Di Giovine et al., 2011; Zhang et al., 2011), HSV-2 gD (4MYV), HSV-2 gD bound to nectin-1 (4MYW) (Lu et al., 2014), PRV gD (5X5V), PRV gD bound to nectin-1 (5X5W) (Li et al., 2017a), HSV-2 gHgL (3M1C) (Chowdary et al., 2010), PRV gH (2XQY) (Backovic et al., 2010), VZV gHgL (4XHJ) (Xing et al., 2015), postfusion forms of HSV-1 gB (2GUM, 2NWF, and 5V2S) (Cooper et al., 2018; Heldwein et al., 2006; Stampfer et al., 2010), and PRV gB (6ESC and 5YS6) (Li et al., 2017b; Vallbracht et al., 2017). A model of membrane-anchored HSV-1 gB generated using cryoET also is available (5FZ2) (Zeev-Ben-Mordehai et al., 2016).

\section{Acknowledgements}

TMC is supported by grants $\mathrm{Al}-18289, \mathrm{Al}-142940$, and $\mathrm{Al}-139618$, and SAC is supported by grant Al-148478 from the National Institute of Allergy and Infectious Diseases of the National Institutes of Health.

\section{References}

Akkarawongsa, R., Pocaro, N.E., Case, G., Kolb, A.W., and Brandt, C.R. (2009). Multiple peptides homologous to herpes simplex virus type 1 glycoprotein B inhibit viral infection. Antimicrob Agents Chemother 53, 987-996.

Arii, J., Goto, H., Suenaga, T., Oyama, M., Kozuka-Hata, H., Imai, T., Minowa, A., Akashi, H., Arase, H., Kawaoka, Y., et al. (2010a). Non-muscle myosin IIA is a functional entry receptor for herpes simplex virus-1. Nature 467, 859-862. 
Arii, J., Wang, J., Morimoto, T., Suenaga, T., Akashi, H., Arase, H., and Kawaguchi, Y. (2010b). A single-amino-acid substitution in herpes simplex virus 1 envelope glycoprotein $B$ at a site required for binding to the paired immunoglobulin-like type 2 receptor alpha (PILRalpha) abrogates PILRalphadependent viral entry and reduces pathogenesis. J Virol 84, 10773-10783.

Atanasiu, D., Cairns, T.M., Whitbeck, J.C., Saw, W.T., Rao, S., Eisenberg, R.J., and Cohen, G.H. (2013). Regulation of herpes simplex virus gB-induced cellcell fusion by mutant forms of $\mathrm{gH} / \mathrm{gL}$ in the absence of $\mathrm{gD}$ and cellular receptors. mBio 4.

Atanasiu, D., Saw, W.T., Cohen, G.H., and Eisenberg, R.J. (2010a). Cascade of events governing cell-cell fusion induced by herpes simplex virus glycoproteins gD, gH/gL, and gB. J Virol 84, 12292-12299.

Atanasiu, D., Saw, W.T., Eisenberg, R.J., and Cohen, G.H. (2016). Regulation of HSV glycoprotein induced cascade of events governing cell-cell fusion. J Virol.

Atanasiu, D., Saw, W.T., Lazear, E., Whitbeck, J.C., Cairns, T.M., Lou, H., Eisenberg, R.J., and Cohen, G.H. (2018). Using Antibodies and Mutants To Localize the Presumptive $\mathrm{gH} / \mathrm{gL}$ Binding Site on Herpes Simplex Virus gD. J Virol 92.

Atanasiu, D., Whitbeck, J.C., Cairns, T.M., Reilly, B., Cohen, G.H., and Eisenberg, R.J. (2007). Bimolecular complementation reveals that glycoproteins $\mathrm{gB}$ and $\mathrm{gH} / \mathrm{gL}$ of herpes simplex virus interact with each other during cell fusion. Proceedings of the National Academy of Sciences of the United States of America 104, 18718-18723.

Atanasiu, D., Whitbeck, J.C., de Leon, M.P., Lou, H., Hannah, B.P., Cohen, G.H., and Eisenberg, R.J. (2010b). Bimolecular complementation defines functional regions of Herpes simplex virus $\mathrm{gB}$ that are involved with $\mathrm{gH} / \mathrm{gL}$ as a necessary step leading to cell fusion. J Virol 84, 3825-3834.

Avitabile, E., Forghieri, C., and Campadelli-Fiume, G. (2007). Complexes between herpes simplex virus glycoproteins $\mathrm{gD}, \mathrm{gB}$, and $\mathrm{gH}$ detected in cells by complementation of split enhanced green fluorescent protein. J Virol 81, $11532-11537$. 
Awasthi, S., Belshe, R.B., and Friedman, H.M. (2014). Better neutralization of herpes simplex virus type 1 (HSV-1) than HSV-2 by antibody from recipients of GlaxoSmithKline HSV-2 glycoprotein D2 subunit vaccine. The Journal of infectious diseases 210, 571-575.

Awasthi, S., Mahairas, G.G., Shaw, C.E., Huang, M.L., Koelle, D.M., Posavad, C., Corey, L., and Friedman, H.M. (2015). A Dual-Modality Herpes Simplex Virus 2 Vaccine for Preventing Genital Herpes by Using Glycoprotein C and D Subunit Antigens To Induce Potent Antibody Responses and Adenovirus Vectors Containing Capsid and Tegument Proteins as T Cell Immunogens. J Virol 89, 8497-8509.

Babic, N., Klupp, B.G., Makoschey, B., Karger, A., Flamand, A., and Mettenleiter, T.C. (1996). Glycoprotein $\mathrm{gH}$ of pseudorabies virus is essential for penetration and propagation in cell culture and in the nervous system of mice. J Gen Virol 77 ( Pt 9), 2277-2285.

Backovic, M., DuBois, R.M., Cockburn, J.J., Sharff, A.J., Vaney, M.C., Granzow, H., Klupp, B.G., Bricogne, G., Mettenleiter, T.C., and Rey, F.A. (2010). Structure of a core fragment of glycoprotein $H$ from pseudorabies virus in complex with antibody. Proceedings of the National Academy of Sciences of the United States of America 107, 22635-22640.

Backovic, M., and Jardetzky, T.S. (2009). Class III viral membrane fusion proteins. Current opinion in structural biology 19, 189-196.

Backovic, M., Jardetzky, T.S., and Longnecker, R. (2007). Hydrophobic residues that form putative fusion loops of Epstein-Barr virus glycoprotein $B$ are critical for fusion activity. J Virol 81, 9596-9600.

Backovic, M., Longnecker, R., and Jardetzky, T.S. (2009). Structure of a trimeric variant of the Epstein-Barr virus glycoprotein $B$. Proceedings of the National Academy of Sciences of the United States of America 106, 2880-2885.

Baghian, A., Huang, L., Newman, S., Jayachandra, S., and Kousoulas, K.G. (1993). Truncation of the carboxy-terminal 28 amino acids of glycoprotein $B$ specified by herpes simplex virus type 1 mutant amb1511-7 causes extensive cell fusion. J Virol 67, 2396-2401. 
Baquero, E., Albertini, A.A., Raux, H., Buonocore, L., Rose, J.K., Bressanelli, S., and Gaudin, Y. (2015). Structure of the low pH conformation of Chandipura virus $G$ reveals important features in the evolution of the vesiculovirus glycoprotein. PLoS Pathog 11, e1004756.

Belot, L., Ouldali, M., Roche, S., Legrand, P., Gaudin, Y., and Albertini, A.A. (2020). Crystal structure of Mokola virus glycoprotein in its post-fusion conformation. PLoS Pathog 16, e1008383.

Bender, F.C., Samanta, M., Heldwein, E.E., de Leon, M.P., Bilman, E., Lou, H., Whitbeck, J.C., Eisenberg, R.J., and Cohen, G.H. (2007). Antigenic and mutational analyses of herpes simplex virus glycoprotein $B$ reveal four functional regions. J Virol 81, 3827-3841.

Birlea, M., Owens, G.P., Eshleman, E.M., Ritchie, A., Traktinskiy, I., Bos, N., Seitz, S., Azarkh, Y., Mahalingam, R., Gilden, D., et al. (2013). Human antivaricella-zoster virus (VZV) recombinant monoclonal antibody produced after Zostavax immunization recognizes the $\mathrm{gH} / \mathrm{gL}$ complex and neutralizes VZV infection. J Virol 87, 415-421.

Bohm, S.W., Backovic, M., Klupp, B.G., Rey, F.A., Mettenleiter, T.C., and Fuchs, W. (2016). Functional Characterization of Glycoprotein H Chimeras Composed of Conserved Domains of the Pseudorabies Virus and Herpes Simplex Virus 1 Homologs. J Virol 90, 421-432.

Browne, H., Bruun, B., and Minson, T. (2001). Plasma membrane requirements for cell fusion induced by herpes simplex virus type 1 glycoproteins gB, gD, gH and gL. J Gen Virol 82, 1419-1422.

Browne, H.M., Bruun, B.C., and Minson, A.C. (1996). Characterization of herpes simplex virus type 1 recombinants with mutations in the cytoplasmic tail of glycoprotein H. J Gen Virol 77 ( Pt 10), 2569-2573.

Buckmaster, E.A., Gompels, U., and Minson, A. (1984). Characterisation and physical mapping of an HSV-1 glycoprotein of approximately $115 \times 10(3)$ molecular weight. Virology 139, 408-413.

Burke, H.G., and Heldwein, E.E. (2015). Crystal Structure of the Human Cytomegalovirus Glycoprotein B. PLoS Pathog 11, e1005227.

Cai, W.H., Gu, B., and Person, S. (1988). Role of glycoprotein B of herpes simplex virus type 1 in viral entry and cell fusion. J Virol 62, 2596-2604. 
Cairns, T.M., Ditto, N.T., Atanasiu, D., Lou, H., Brooks, B.D., Saw, W.T., Eisenberg, R.J., and Cohen, G.H. (2019). Surface Plasmon Resonance Reveals Direct Binding of Herpes Simplex Virus Glycoproteins $\mathrm{gH} / \mathrm{gL}$ to $\mathrm{gD}$ and Locates a gH/gL Binding Site on gD. J Virol 93.

Cairns, T.M., Ditto, N.T., Lou, H., Brooks, B.D., Atanasiu, D., Eisenberg, R.J., and Cohen, G.H. (2017). Global sensing of the antigenic structure of herpes simplex virus gD using high-throughput array-based SPR imaging. PLoS Pathog 13, e1006430.

Cairns, T.M., Friedman, L.S., Lou, H., Whitbeck, J.C., Shaner, M.S., Cohen, G.H., and Eisenberg, R.J. (2007). N-terminal mutants of herpes simplex virus type $2 \mathrm{gH}$ are transported without $\mathrm{gL}$ but require $\mathrm{gL}$ for function. J Virol 81, 5102-5111.

Cairns, T.M., Huang, Z.Y., Gallagher, J.R., Lin, Y., Lou, H., Whitbeck, J.C., Wald, A., Cohen, G.H., and Eisenberg, R.J. (2015). Patient-Specific Neutralizing Antibody Responses to Herpes Simplex Virus Are Attributed to Epitopes on gD, gB, or Both and Can Be Type Specific. J Virol 89, 9213-9231.

Cairns, T.M., Huang, Z.Y., Whitbeck, J.C., Ponce de Leon, M., Lou, H., Wald, A., Krummenacher, C., Eisenberg, R.J., and Cohen, G.H. (2014). Dissection of the antibody response against herpes simplex virus glycoproteins in naturally infected humans. J Virol 88, 12612-12622.

Cairns, T.M., Landsburg, D.J., Whitbeck, J.C., Eisenberg, R.J., and Cohen, G.H. (2005). Contribution of cysteine residues to the structure and function of herpes simplex virus $\mathrm{gH} / \mathrm{gL}$. Virology 332, 550-562.

Cairns, T.M., Shaner, M.S., Zuo, Y., Ponce-de-Leon, M., Baribaud, I., Eisenberg, R.J., Cohen, G.H., and Whitbeck, J.C. (2006). Epitope mapping of herpes simplex virus type $2 \mathrm{gH} / \mathrm{gL}$ defines distinct antigenic sites, including some associated with biological function. J Virol 80, 2596-2608.

Cairns, T.M., Whitbeck, J.C., Lou, H., Heldwein, E.E., Chowdary, T.K., Eisenberg, R.J., and Cohen, G.H. (2011). Capturing the herpes simplex virus core fusion complex (gB-gH/gL) in an acidic environment. J Virol 85, 6175-6184. 
Campadelli-Fiume, G., Petrovic, B., Leoni, V., Gianni, T., Avitabile, E., Casiraghi, C., and Gatta, V. (2016). Retargeting Strategies for Oncolytic Herpes Simplex Viruses. Viruses 8, 63.

Carfi, A., Willis, S.H., Whitbeck, J.C., Krummenacher, C., Cohen, G.H., Eisenberg, R.J., and Wiley, D.C. (2001). Herpes simplex virus glycoprotein D bound to the human receptor HveA. Molecular cell 8, 169-179.

Ch'ng, T.H., Spear, P.G., Struyf, F., and Enquist, L.W. (2007). Glycoprotein Dindependent spread of pseudorabies virus infection in cultured peripheral nervous system neurons in a compartmented system. J Virol 81, 10742-10757.

Chandramouli, S., Ciferri, C., Nikitin, P.A., Calo, S., Gerrein, R., Balabanis, K., Monroe, J., Hebner, C., Lilja, A.E., Settembre, E.C., et al. (2015). Structure of HCMV glycoprotein B in the postfusion conformation bound to a neutralizing human antibody. Nature communications 6, 8176.

Chen, J., Sathiyamoorthy, K., Zhang, X., Schaller, S., Perez White, B.E., Jardetzky, T.S., and Longnecker, R. (2018). Ephrin receptor A2 is a functional entry receptor for Epstein-Barr virus. Nat Microbiol 3, 172-180.

Chen, J., Zhang, X., Schaller, S., Jardetzky, T.S., and Longnecker, R. (2019). Ephrin Receptor A4 is a New Kaposi's Sarcoma-Associated Herpesvirus Virus Entry Receptor. mBio 10.

Chen, J.J., Zhu, Z., Gershon, A.A., and Gershon, M.D. (2004). Mannose 6phosphate receptor dependence of varicella zoster virus infection in vitro and in the epidermis during varicella and zoster. Cell 119, 915-926.

Chesnokova, L.S., and Hutt-Fletcher, L.M. (2011). Fusion of Epstein-Barr virus with epithelial cells can be triggered by alphavbeta5 in addition to alphavbeta6 and alphavbeta8, and integrin binding triggers a conformational change in glycoproteins $\mathrm{gHgL}$. J Virol 85, 13214-13223.

Chesnokova, L.S., Nishimura, S.L., and Hutt-Fletcher, L.M. (2009). Fusion of epithelial cells by Epstein-Barr virus proteins is triggered by binding of viral glycoproteins $\mathrm{gHgL}$ to integrins alphavbeta6 or alphavbeta8. Proceedings of the National Academy of Sciences of the United States of America 106, 20464-20469. 
Chouljenko, V.N., lyer, A.V., Chowdhury, S., Kim, J., and Kousoulas, K.G. (2010). The herpes simplex virus type 1 UL20 protein and the amino terminus of glycoprotein $\mathrm{K}(\mathrm{gK})$ physically interact with gB. J Virol 84, 8596-8606.

Chowdary, T.K., Cairns, T.M., Atanasiu, D., Cohen, G.H., Eisenberg, R.J., and Heldwein, E.E. (2010). Crystal structure of the conserved herpesvirus fusion regulator complex gH-gL. Nature structural and molecular biology 17, 882-888.

Ciferri, C., Chandramouli, S., Donnarumma, D., Nikitin, P.A., Cianfrocco, M.A., Gerrein, R., Feire, A.L., Barnett, S.W., Lilja, A.E., Rappuoli, R., et al. (2015). Structural and biochemical studies of $\mathrm{HCMV} \mathrm{gH} / \mathrm{gL} / \mathrm{gO}$ and Pentamer reveal mutually exclusive cell entry complexes. Proceedings of the National Academy of Sciences of the United States of America 112, 1767-1772.

Cocchi, F., Fusco, D., Menotti, L., Gianni, T., Eisenberg, R.J., Cohen, G.H., and Campadelli-Fiume, G. (2004a). The soluble ectodomain of herpes simplex virus gD contains a membrane-proximal pro-fusion domain and suffices to mediate virus entry. Proceedings of the National Academy of Sciences of the United States of America 101, 7445-7450.

Cocchi, F., Menotti, L., Di Ninni, V., Lopez, M., and Campadelli-Fiume, G. (2004b). The herpes simplex virus JMP mutant enters receptor-negative $J$ cells through a novel pathway independent of the known receptors nectin1, HveA, and nectin2. J Virol 78, 4720-4729.

Cocchi, F., Menotti, L., Mirandola, P., Lopez, M., and Campadelli-Fiume, G. (1998). The ectodomain of a novel member of the immunoglobulin subfamily related to the poliovirus receptor has the attributes of a bona fide receptor for herpes simplex virus types 1 and 2 in human cells. J Virol 72, 9992-10002.

Cohen, G.H., Dietzschold, B., Ponce de Leon, M., Long, D., Golub, E., Varrichio, A., Pereira, L., and Eisenberg, R.J. (1984). Localization and synthesis of an antigenic determinant of herpes simplex virus glycoprotein $D$ that stimulates the production of neutralizing antibody. J Virol 49, 102-108.

Cole, N.L., and Grose, C. (2003). Membrane fusion mediated by herpesvirus glycoproteins: the paradigm of varicella-zoster virus. Rev Med Virol 13, 207-222. 
Compton, T., Nepomuceno, R.R., and Nowlin, D.M. (1992). Human cytomegalovirus penetrates host cells by $\mathrm{pH}$-independent fusion at the cell surface. Virology 191, 387-395.

Connolly, S.A., Landsburg, D.J., Carfi, A., Wiley, D.C., Eisenberg, R.J., and Cohen, G.H. (2002). Structure-based analysis of the herpes simplex virus glycoprotein $D$ binding site present on herpesvirus entry mediator HveA (HVEM). J Virol 76, 10894-10904.

Connolly, S.A., and Longnecker, R. (2012). Residues within the C-terminal arm of the herpes simplex virus 1 glycoprotein $B$ ectodomain contribute to its refolding during the fusion step of virus entry. J Virol 86, 6386-6393.

Connolly, S.A., Whitbeck, J.J., Rux, A.H., Krummenacher, C., van Drunen Littel-van den Hurk, S., Cohen, G.H., and Eisenberg, R.J. (2001). Glycoprotein D homologs in herpes simplex virus type 1, pseudorabies virus, and bovine herpes virus type 1 bind directly to human $\mathrm{HveC}$ (nectin-1) with different affinities. Virology 280, 7-18.

Cooper, R.S., Georgieva, E.R., Borbat, P.P., Freed, J.H., and Heldwein, E.E. (2018). Structural basis for membrane anchoring and fusion regulation of the herpes simplex virus fusogen gB. Nature structural and molecular biology 25 , 416-424.

Cooper, R.S., and Heldwein, E.E. (2015). Herpesvirus gB: A Finely Tuned Fusion Machine. Viruses 7, 6552-6569.

Desai, P.J., Schaffer, P.A., and Minson, A.C. (1988). Excretion of non-infectious virus particles lacking glycoprotein $\mathrm{H}$ by a temperature-sensitive mutant of herpes simplex virus type 1: evidence that $\mathrm{gH}$ is essential for virion infectivity. J Gen Virol 69 ( Pt 6), 1147-1156.

Di Giovine, P., Settembre, E.C., Bhargava, A.K., Luftig, M.A., Lou, H., Cohen, G.H., Eisenberg, R.J., Krummenacher, C., and Carfi, A. (2011). Structure of herpes simplex virus glycoprotein $D$ bound to the human receptor nectin-1. PLoS Pathog 7, e1002277.

Diakidi-Kosta, A., Michailidou, G., Kontogounis, G., Sivropoulou, A., and Arsenakis, M. (2003). A single amino acid substitution in the cytoplasmic tail of the glycoprotein B of herpes simplex virus 1 affects both syncytium formation and binding to intracellular heparan sulfate. Virus Res 93, 99-108. 
Dollery, S.J., Delboy, M.G., and Nicola, A.V. (2010a). Low pH-induced conformational change in herpes simplex virus glycoprotein B. J Virol 84, 3759-3766.

Dollery, S.J., Lane, K.D., Delboy, M.G., Roller, D.G., and Nicola, A.V. (2010b). Role of the UL45 protein in herpes simplex virus entry via low $\mathrm{pH}$-dependent endocytosis and its relationship to the conformation and function of glycoprotein B. Virus Res 149, 115-118.

Dollery, S.J., Wright, C.C., Johnson, D.C., and Nicola, A.V. (2011). Low-pHdependent changes in the conformation and oligomeric state of the prefusion form of herpes simplex virus glycoprotein B are separable from fusion activity. J Virol 85, 9964-9973.

Dolter, K.E., Ramaswamy, R., and Holland, T.C. (1994). Syncytial mutations in the herpes simplex virus type $1 \mathrm{gK}$ (UL53) gene occur in two distinct domains. J Virol 68, 8277-8281.

Du, R., Wang, L., Xu, H., Wang, Z., Zhang, T., Wang, M., Ning, Y., Deng, F., $\mathrm{Hu}$, Z., Wang, H., et al. (2017). A novel glycoprotein D-specific monoclonal antibody neutralizes herpes simplex virus. Antiviral research 147, 131-141.

Dubin, G., and Jiang, H. (1995). Expression of herpes simplex virus type 1 glycoprotein $\mathrm{L}(\mathrm{gL})$ in transfected mammalian cells: evidence that $\mathrm{gL}$ is not independently anchored to cell membranes. J Virol 69, 4564-4568.

Duus, K.M., and Grose, C. (1996). Multiple regulatory effects of varicella-zoster virus (VZV) gL on trafficking patterns and fusogenic properties of $\mathrm{VZV} \mathrm{gH}$. J Virol 70, 8961-8971.

Duus, K.M., Hatfield, C., and Grose, C. (1995). Cell surface expression and fusion by the varicella-zoster virus $\mathrm{gH}: \mathrm{gL}$ glycoprotein complex: analysis by laser scanning confocal microscopy. Virology 210, 429-440.

Edwards, R.G., Kopp, S.J., Karaba, A.H., Wilcox, D.R., and Longnecker, R. (2015). Herpesvirus entry mediator on radiation-resistant cell lineages promotes ocular herpes simplex virus 1 pathogenesis in an entryindependent manner. mBio 6, e01532-01515.

Edwards, R.G., and Longnecker, R. (2017). Herpesvirus Entry Mediator and Ocular Herpesvirus Infection: More than Meets the Eye. J Virol 91. 
El Kasmi, I., and Lippe, R. (2015). Herpes simplex virus $1 \mathrm{gN}$ partners with gM to modulate the viral fusion machinery. J Virol 89, 2313-2323.

Engel, J.P., Boyer, E.P., and Goodman, J.L. (1993). Two novel single amino acid syncytial mutations in the carboxy terminus of glycoprotein $B$ of herpes simplex virus type 1 confer a unique pathogenic phenotype. Virology 192, 112-120.

Falanga, A., Tarallo, R., Vitiello, G., Vitiello, M., Perillo, E., Cantisani, M., D'Errico, G., Galdiero, M., and Galdiero, S. (2012). Biophysical characterization and membrane interaction of the two fusion loops of glycoprotein B from herpes simplex type I virus. PloS one 7, e32186.

Fan, Q., Kopp, S.J., Connolly, S.A., and Longnecker, R. (2017). StructureBased Mutations in the Herpes Simplex Virus 1 Glycoprotein B Ectodomain Arm Impart a Slow-Entry Phenotype. mBio 8.

Fan, Q., Lin, E., Satoh, T., Arase, H., and Spear, P.G. (2009). Differential effects on cell fusion activity of mutations in herpes simplex virus 1 glycoprotein $\mathrm{B}(\mathrm{gB})$ dependent on whether a $\mathrm{gD}$ receptor or a $\mathrm{gB}$ receptor is overexpressed. J Virol 83, 7384-7390.

Fan, Q., and Longnecker, R. (2012). Is nectin-1 the "master" receptor for deadly herpes $B$ virus infection? Virulence 3, 405.

Fan, Q., Longnecker, R., and Connolly, S.A. (2014). Substitution of herpes simplex virus 1 entry glycoproteins with those of saimiriine herpesvirus 1 reveals a $\mathrm{gD}-\mathrm{gH} / \mathrm{gL}$ functional interaction and a region within the $\mathrm{gD}$ profusion domain that is critical for fusion. J Virol 88, 6470-6482.

Fan, Q., Longnecker, R., and Connolly, S.A. (2015). A Functional Interaction between Herpes Simplex Virus 1 Glycoprotein $\mathrm{gH} / \mathrm{gL}$ Domains I and II and $\mathrm{gD}$ Is Defined by Using Alphaherpesvirus $\mathrm{gH}$ and $\mathrm{gL}$ Chimeras. J Virol 89, 7159-7169.

Fan, Z., Grantham, M.L., Smith, M.S., Anderson, E.S., Cardelli, J.A., and Muggeridge, M.I. (2002). Truncation of herpes simplex virus type 2 glycoprotein B increases its cell surface expression and activity in cell-cell fusion, but these properties are unrelated. J Virol 76, 9271-9283.

Ferlin, A., Raux, H., Baquero, E., Lepault, J., and Gaudin, Y. (2014). Characterization of $\mathrm{pH}$-sensitive molecular switches that trigger the structural 
transition of vesicular stomatitis virus glycoprotein from the postfusion state toward the prefusion state. J Virol 88, 13396-13409.

Foa-Tomasi, L., Avitabile, E., Boscaro, A., Brandimarti, R., Gualandri, R., Manservigi, R., Dall'Olio, F., Serafini-Cessi, F., and Fiume, G.C. (1991). Herpes simplex virus (HSV) glycoprotein $\mathrm{H}$ is partially processed in a cell line that expresses the glycoprotein and fully processed in cells infected with deletion or ts mutants in the known HSV glycoproteins. Virology 180, 474-482.

Fontana, J., Atanasiu, D., Saw, W.T., Gallagher, J.R., Cox, R.G., Whitbeck, J.C., Brown, L.M., Eisenberg, R.J., and Cohen, G.H. (2017). The Fusion Loops of the Initial Prefusion Conformation of Herpes Simplex Virus 1 Fusion Protein Point Toward the Membrane. mBio 8.

Forrester, A., Farrell, H., Wilkinson, G., Kaye, J., Davis-Poynter, N., and Minson, T. (1992). Construction and properties of a mutant of herpes simplex virus type 1 with glycoprotein $\mathrm{H}$ coding sequences deleted. J Virol 66, 341-348.

Foster, T.P., Melancon, J.M., and Kousoulas, K.G. (2001). An alpha-helical domain within the carboxyl terminus of herpes simplex virus type 1 (HSV-1) glycoprotein $\mathrm{B}(\mathrm{gB})$ is associated with cell fusion and resistance to heparin inhibition of cell fusion. Virology 287, 18-29.

Frampton, A.R., Jr., Stolz, D.B., Uchida, H., Goins, W.F., Cohen, J.B., and Glorioso, J.C. (2007). Equine herpesvirus 1 enters cells by two different pathways, and infection requires the activation of the cellular kinase ROCK1. J Virol 81, 10879-10889.

Fuchs, W., Backovic, M., Klupp, B.G., Rey, F.A., and Mettenleiter, T.C. (2012). Structure-based mutational analysis of the highly conserved domain IV of glycoprotein $\mathrm{H}$ of pseudorabies virus. J Virol 86, 8002-8013.

Fuller, A.O., and Lee, W.C. (1992). Herpes simplex virus type 1 entry through a cascade of virus-cell interactions requires different roles of $\mathrm{gD}$ and $\mathrm{gH}$ in penetration. J Virol 66, 5002-5012.

Fuller, A.O., and Spear, P.G. (1987). Anti-glycoprotein D antibodies that permit adsorption but block infection by herpes simplex virus 1 prevent virion-cell 
fusion at the cell surface. Proceedings of the National Academy of Sciences of the United States of America 84, 5454-5458.

Gage, P.J., Levine, M., and Glorioso, J.C. (1993). Syncytium-inducing mutations localize to two discrete regions within the cytoplasmic domain of herpes simplex virus type 1 glycoprotein B. J Virol 67, 2191-2201.

Galdiero, M., Whiteley, A., Bruun, B., Bell, S., Minson, T., and Browne, H. (1997). Site-directed and linker insertion mutagenesis of herpes simplex virus type 1 glycoprotein H. J Virol 71, 2163-2170.

Galdiero, S., Falanga, A., Vitiello, M., Browne, H., Pedone, C., and Galdiero, M. (2005). Fusogenic domains in herpes simplex virus type 1 glycoprotein $\mathrm{H}$. J Biol Chem 280, 28632-28643.

Galdiero, S., Falanga, A., Vitiello, M., D'Isanto, M., Collins, C., Orrei, V., Browne, H., Pedone, C., and Galdiero, M. (2007). Evidence for a role of the membrane-proximal region of herpes simplex virus Type 1 glycoprotein $\mathrm{H}$ in membrane fusion and virus inhibition. ChemBioChem 8, 885-895.

Galdiero, S., Vitiello, M., D'Isanto, M., Falanga, A., Collins, C., Raieta, K., Pedone, C., Browne, H., and Galdiero, M. (2006). Analysis of synthetic peptides from heptad-repeat domains of herpes simplex virus type 1 glycoproteins H and B. J Gen Virol 87, 1085-1097.

Galen, B., Cheshenko, N., Tuyama, A., Ramratnam, B., and Herold, B.C. (2006). Access to nectin favors herpes simplex virus infection at the apical surface of polarized human epithelial cells. J Virol 80, 12209-12218.

Gallagher, J.R., Atanasiu, D., Saw, W.T., Paradisgarten, M.J., Whitbeck, J.C., Eisenberg, R.J., and Cohen, G.H. (2014). Functional fluorescent protein insertions in herpes simplex virus $\mathrm{gB}$ report on $\mathrm{gB}$ conformation before and after execution of membrane fusion. PLoS Pathog 10, e1004373.

Gallagher, J.R., Saw, W.T., Atanasiu, D., Lou, H., Eisenberg, R.J., and Cohen, G.H. (2013). Displacement of the $C$ terminus of herpes simplex virus $g D$ is sufficient to expose the fusion-activating interfaces on gD. J Virol 87, 12656-12666.

Gianni, T., Amasio, M., and Campadelli-Fiume, G. (2009). Herpes simplex virus $\mathrm{gD}$ forms distinct complexes with fusion executors $\mathrm{gB}$ and $\mathrm{gH} / \mathrm{gL}$ in part through the C-terminal profusion domain. J Biol Chem 284, 17370-17382. 
Gianni, T., and Campadelli-Fiume, G. (2012). alphaVbeta3-integrin relocalizes nectin1 and routes herpes simplex virus to lipid rafts. J Virol 86, 2850-2855.

Gianni, T., Martelli, P.L., Casadio, R., and Campadelli-Fiume, G. (2005a). The ectodomain of herpes simplex virus glycoprotein $\mathrm{H}$ contains a membrane alpha-helix with attributes of an internal fusion peptide, positionally conserved in the herpesviridae family. J Virol 79, 2931-2940.

Gianni, T., Menotti, L., and Campadelli-Fiume, G. (2005b). A heptad repeat in herpes simplex virus $1 \mathrm{gH}$, located downstream of the alpha-helix with attributes of a fusion peptide, is critical for virus entry and fusion. J Virol 79, 7042-7049.

Gianni, T., Salvioli, S., Chesnokova, L.S., Hutt-Fletcher, L.M., and CampadelliFiume, G. (2013). alphavbeta6- and alphavbeta8-integrins serve as interchangeable receptors for $\mathrm{HSV} \mathrm{gH} / \mathrm{gL}$ to promote endocytosis and activation of membrane fusion. PLoS Pathog 9, e1003806.

Gompels, U.A., Carss, A.L., Saxby, C., Hancock, D.C., Forrester, A., and Minson, A.C. (1991). Characterization and sequence analyses of antibodyselected antigenic variants of herpes simplex virus show a conformationally complex epitope on glycoprotein H. J Virol 65, 2393-2401.

Granzow, H., Weiland, F., Jons, A., Klupp, B.G., Karger, A., and Mettenleiter, T.C. (1997). Ultrastructural analysis of the replication cycle of pseudorabies virus in cell culture: a reassessment. J Virol 71, 2072-2082.

Gruenheid, S., Gatzke, L., Meadows, H., and Tufaro, F. (1993). Herpes simplex virus infection and propagation in a mouse $L$ cell mutant lacking heparan sulfate proteoglycans. J Virol 67, 93-100.

Grunewald, K., Desai, P., Winkler, D.C., Heymann, J.B., Belnap, D.M., Baumeister, W., and Steven, A.C. (2003). Three-dimensional structure of herpes simplex virus from cryo-electron tomography. Science 302, 1396-1398.

Haanes, E.J., Nelson, C.M., Soule, C.L., and Goodman, J.L. (1994). The UL45 gene product is required for herpes simplex virus type 1 glycoprotein $B-$ induced fusion. J Virol 68, 5825-5834.

Hahn, A.S., Kaufmann, J.K., Wies, E., Naschberger, E., Panteleev-Ivlev, J., Schmidt, K., Holzer, A., Schmidt, M., Chen, J., Konig, S., et al. (2012). The 
ephrin receptor tyrosine kinase A2 is a cellular receptor for Kaposi's sarcomaassociated herpesvirus. Nature medicine 18, 961-966.

Han, J., Chadha, P., Starkey, J.L., and Wills, J.W. (2012). Function of glycoprotein $E$ of herpes simplex virus requires coordinated assembly of three tegument proteins on its cytoplasmic tail. Proceedings of the National Academy of Sciences of the United States of America 109, 19798-19803.

Handler, C.G., Cohen, G.H., and Eisenberg, R.J. (1996). Cross-linking of glycoprotein oligomers during herpes simplex virus type 1 entry. J Virol 70, 6076-6082.

Hannah, B.P., Cairns, T.M., Bender, F.C., Whitbeck, J.C., Lou, H., Eisenberg, R.J., and Cohen, G.H. (2009). Herpes simplex virus glycoprotein B associates with target membranes via its fusion loops. J Virol 83, 6825-6836.

Harman, A., Browne, H., and Minson, T. (2002). The transmembrane domain and cytoplasmic tail of herpes simplex virus type 1 glycoprotein $\mathrm{H}$ play a role in membrane fusion. J Virol 76, 10708-10716.

Harrison, S.C. (2015). Viral membrane fusion. Virology 479-480, 498-507.

Hasebe, R., Sasaki, M., Sawa, H., Wada, R., Umemura, T., and Kimura, T. (2009). Infectious entry of equine herpesvirus-1 into host cells through different endocytic pathways. Virology 393, 198-209.

Heineman, T.C., and Hall, S.L. (2002). Role of the varicella-zoster virus gB cytoplasmic domain in gB transport and viral egress. J Virol 76, 591-599.

Heldwein, E.E., Lou, H., Bender, F.C., Cohen, G.H., Eisenberg, R.J., and Harrison, S.C. (2006). Crystal structure of glycoprotein B from herpes simplex virus 1. Science 313, 217-220.

Herold, B.C., Visalli, R.J., Susmarski, N., Brandt, C.R., and Spear, P.G. (1994). Glycoprotein C-independent binding of herpes simplex virus to cells requires cell surface heparan sulfate and glycoprotein B. J Gen Virol 75, 1211-1222.

Herold, B.C., WuDunn, D., Soltys, N., and Spear, P.G. (1991). Glycoprotein C of herpes simplex virus type 1 plays a principal role in the adsorption of virus to cells and in infectivity. J Virol 65, 1090-1098.

Highlander, S.L., Sutherland, S.L., Gage, P.J., Johnson, D.C., Levine, M., and Glorioso, J.C. (1987). Neutralizing monoclonal antibodies specific for herpes simplex virus glycoprotein D inhibit virus penetration. J Virol 61, 3356-3364. 
Hook, L.M., Cairns, T.M., Awasthi, S., Brooks, B.D., Ditto, N.T., Eisenberg, R.J., Cohen, G.H., and Friedman, H.M. (2018). Vaccine-induced antibodies to herpes simplex virus glycoprotein D epitopes involved in virus entry and cellto-cell spread correlate with protection against genital disease in guinea pigs. PLoS Pathog 14, e1007095.

Hutchinson, L., Browne, H., Wargent, V., Davis-Poynter, N., Primorac, S., Goldsmith, K., Minson, A.C., and Johnson, D.C. (1992). A novel herpes simplex virus glycoprotein, $\mathrm{gL}$, forms a complex with glycoprotein $\mathrm{H}(\mathrm{gH})$ and affects normal folding and surface expression of $\mathrm{gH}$. J Virol 66, 2240-2250.

Hutt-Fletcher, L.M. (2007). Epstein-Barr virus entry. J Virol 81, 7825-7832.

Jackson, J.O., Lin, E., Spear, P.G., and Longnecker, R. (2010). Insertion mutations in herpes simplex virus 1 glycoprotein $\mathrm{H}$ reduce cell surface expression, slow the rate of cell fusion, or abrogate functions in cell fusion and viral entry. J Virol 84, 2038-2046.

Jambunathan, N., Charles, A.S., Subramanian, R., Saied, A.A., Naderi, M., Rider, P., Brylinski, M., Chouljenko, V.N., and Kousoulas, K.G. (2015). Deletion of a Predicted beta-Sheet Domain within the Amino Terminus of Herpes Simplex Virus Glycoprotein K Conserved among Alphaherpesviruses Prevents Virus Entry into Neuronal Axons. J Virol 90, 2230-2239.

Johnson, D.C., Burke, R.L., and Gregory, T. (1990). Soluble forms of herpes simplex virus glycoprotein D bind to a limited number of cell surface receptors and inhibit virus entry into cells. J Virol 64, 2569-2576.

Jones, N.A., and Geraghty, R.J. (2004). Fusion activity of lipid-anchored envelope glycoproteins of herpes simplex virus type 1. Virology 324, 213-228.

Kadlec, J., Loureiro, S., Abrescia, N.G., Stuart, D.I., and Jones, I.M. (2008). The postfusion structure of baculovirus gp64 supports a unified view of viral fusion machines. Nature structural and molecular biology 15, 1024-1030.

Karaba, A.H., Kopp, S.J., and Longnecker, R. (2011). Herpesvirus entry mediator and nectin-1 mediate herpes simplex virus 1 infection of the murine cornea. J Virol 85, 10041-10047.

Karaba, A.H., Kopp, S.J., and Longnecker, R. (2012). Herpesvirus entry mediator is a serotype specific determinant of pathogenesis in ocular herpes. 
Proceedings of the National Academy of Sciences of the United States of America 109, 20649-20654.

Kim, I.J., Chouljenko, V.N., Walker, J.D., and Kousoulas, K.G. (2013). Herpes simplex virus 1 glycoprotein $M$ and the membrane-associated protein UL11 are required for virus-induced cell fusion and efficient virus entry. J Virol 87 , 8029-8037.

Klupp, B.G., Fuchs, W., Weiland, E., and Mettenleiter, T.C. (1997). Pseudorabies virus glycoprotein $L$ is necessary for virus infectivity but dispensable for virion localization of glycoprotein $\mathrm{H}$. J Virol 71, 7687-7695.

Klupp, B.G., and Mettenleiter, T.C. (1999). Glycoprotein gL-independent infectivity of pseudorabies virus is mediated by a $\mathrm{gD}-\mathrm{gH}$ fusion protein. $\mathrm{J}$ Virol 73, 3014-3022.

Klupp, B.G., Nixdorf, R., and Mettenleiter, T.C. (2000). Pseudorabies virus glycoprotein M inhibits membrane fusion. J Virol 74, 6760-6768.

Klyachkin, Y.M., Stoops, K.D., and Geraghty, R.J. (2006). Herpes simplex virus type 1 glycoprotein $\mathrm{L}$ mutants that fail to promote trafficking of glycoprotein $\mathrm{H}$ and fail to function in fusion can induce binding of glycoprotein L-dependent anti-glycoprotein H antibodies. J Gen Virol 87, 759-767.

Komala Sari, T., Gianopulos, K.A., Weed, D.J., Schneider, S.M., Pritchard, S.M., and Nicola, A.V. (2020). Herpes Simplex Virus Glycoprotein C Regulates Low-pH Entry. mSphere 5.

Kopp, S.J., Banisadr, G., Glajch, K., Maurer, U.E., Grunewald, K., Miller, R.J., Osten, P., and Spear, P.G. (2009). Infection of neurons and encephalitis after intracranial inoculation of herpes simplex virus requires the entry receptor nectin-1. Proceedings of the National Academy of Sciences of the United States of America 106, 17916-17920.

Koyama, A.H., and Uchida, T. (1987). The mode of entry of herpes simplex virus type 1 into Vero cells. Microbiol Immunol 31, 123-130.

Krummenacher, C., Baribaud, F., Ponce de Leon, M., Baribaud, I., Whitbeck, J.C., Xu, R., Cohen, G.H., and Eisenberg, R.J. (2004). Comparative usage of herpesvirus entry mediator $A$ and nectin- 1 by laboratory strains and clinical isolates of herpes simplex virus. Virology 322, 286-299. 
Krummenacher, C., Baribaud, I., Ponce de Leon, M., Whitbeck, J.C., Lou, H., Cohen, G.H., and Eisenberg, R.J. (2000). Localization of a binding site for herpes simplex virus glycoprotein $D$ on herpesvirus entry mediator $C$ by using antireceptor monoclonal antibodies. J Virol 74, 10863-10872.

Krummenacher, C., Nicola, A.V., Whitbeck, J.C., Lou, H., Hou, W., Lambris, J.D., Geraghty, R.J., Spear, P.G., Cohen, G.H., and Eisenberg, R.J. (1998). Herpes simplex virus glycoprotein D can bind to poliovirus receptor-related protein 1 or herpesvirus entry mediator, two structurally unrelated mediators of virus entry. J Virol 72, 7064-7074.

Krummenacher, C., Rux, A.H., Whitbeck, J.C., Ponce-de-Leon, M., Lou, H., Baribaud, I., Hou, W., Zou, C., Geraghty, R.J., Spear, P.G., et al. (1999). The first immunoglobulin-like domain of HveC is sufficient to bind herpes simplex virus gD with full affinity, while the third domain is involved in oligomerization of HveC. J Virol 73, 8127-8137.

Krummenacher, C., Supekar, V.M., Whitbeck, J.C., Lazear, E., Connolly, S.A., Eisenberg, R.J., Cohen, G.H., Wiley, D.C., and Carfi, A. (2005). Structure of unliganded $\mathrm{HSV} \mathrm{gD}$ reveals a mechanism for receptor-mediated activation of virus entry. The EMBO journal 24, 4144-4153.

Laquerre, S., Argnani, R., Anderson, D.B., Zucchini, S., Manservigi, R., and Glorioso, J.C. (1998). Heparan sulfate proteoglycan binding by herpes simplex virus type 1 glycoproteins $B$ and $C$, which differ in their contributions to virus attachment, penetration, and cell-to-cell spread. J Virol 72, 6119-6130.

Lawrence, R., Yabe, T., Hajmohammadi, S., Rhodes, J., McNeely, M., Liu, J., Lamperti, E.D., Toselli, P.A., Lech, M., Spear, P.G., et al. (2007). The principal neuronal gD-type 3-O-sulfotransferases and their products in central and peripheral nervous system tissues. Matrix Biol 26, 442-455.

Lazear, E., Carfi, A., Whitbeck, J.C., Cairns, T.M., Krummenacher, C., Cohen, G.H., and Eisenberg, R.J. (2008). Engineered disulfide bonds in herpes simplex virus type $1 \mathrm{gD}$ separate receptor binding from fusion initiation and viral entry. J Virol 82, 700-709.

Lazear, E., Whitbeck, J.C., Ponce-de-Leon, M., Cairns, T.M., Willis, S.H., Zuo, Y., Krummenacher, C., Cohen, G.H., and Eisenberg, R.J. (2012). Antibody- 
induced conformational changes in herpes simplex virus glycoprotein gD reveal new targets for virus neutralization. J Virol 86, 1563-1576.

Lazear, E., Whitbeck, J.C., Zuo, Y., Carfi, A., Cohen, G.H., Eisenberg, R.J., and Krummenacher, C. (2014). Induction of conformational changes at the $\mathrm{N}$ terminus of herpes simplex virus glycoprotein D upon binding to HVEM and nectin-1. Virology 448, 185-195.

Lee, C.C., Lin, L.L., Chan, W.E., Ko, T.P., Lai, J.S., and Wang, A.H. (2013). Structural basis for the antibody neutralization of herpes simplex virus. Acta crystallographica Section D, Biological crystallography 69, 1935-1945.

Leiva-Torres, G.A., Rochette, P.A., and Pearson, A. (2010). Differential importance of highly conserved residues in UL24 for herpes simplex virus 1 replication in vivo and reactivation. J Gen Virol 91, 1109-1116.

Li, A., Lu, G., Qi, J., Wu, L., Tian, K., Luo, T., Shi, Y., Yan, J., and Gao, G.F. (2017a). Structural basis of nectin-1 recognition by pseudorabies virus glycoprotein D. PLoS Pathog 13, e1006314.

Li, X., Yang, F., Hu, X., Tan, F., Qi, J., Peng, R., Wang, M., Chai, Y., Hao, L., Deng, J., et al. (2017b). Two classes of protective antibodies against Pseudorabies virus variant glycoprotein B: Implications for vaccine design. PLoS Pathog 13, e1006777.

Lin, E., and Spear, P.G. (2007). Random linker-insertion mutagenesis to identify functional domains of herpes simplex virus type 1 glycoprotein B. Proceedings of the National Academy of Sciences of the United States of America 104, 13140-13145.

Locksley, R.M., Killeen, N., and Lenardo, M.J. (2001). The TNF and TNF receptor superfamilies: integrating mammalian biology. Cell 104, 487-501.

Lopez, M., Cocchi, F., Menotti, L., Avitabile, E., Dubreuil, P., and CampadelliFiume, G. (2000). Nectin2alpha (PRR2alpha or HveB) and nectin2delta are low-efficiency mediators for entry of herpes simplex virus mutants carrying the Leu25Pro substitution in glycoprotein D. J Virol 74, 1267-1274.

Lopper, M., and Compton, T. (2004). Coiled-coil domains in glycoproteins B and $\mathrm{H}$ are involved in human cytomegalovirus membrane fusion. J Virol 78 , 8333-8341. 
Lu, G., Zhang, N., Qi, J., Li, Y., Chen, Z., Zheng, C., Gao, G.F., and Yan, J. (2014). Crystal structure of herpes simplex virus $2 \mathrm{gD}$ bound to nectin-1 reveals a conserved mode of receptor recognition. J Virol 88, 13678-13688.

Maresova, L., Pasieka, T.J., and Grose, C. (2001). Varicella-zoster Virus gB and $\mathrm{gE}$ coexpression, but not $\mathrm{gB}$ or $\mathrm{gE}$ alone, leads to abundant fusion and syncytium formation equivalent to those from $\mathrm{gH}$ and $\mathrm{gL}$ coexpression. $\mathrm{J}$ Virol 75, 9483-9492.

Mata, M., Zhang, M., Hu, X., and Fink, D.J. (2001). HveC (nectin-1) is expressed at high levels in sensory neurons, but not in motor neurons, of the rat peripheral nervous system. Journal of neurovirology 7, 476-480.

Matsuura, H., Kirschner, A.N., Longnecker, R., and Jardetzky, T.S. (2010). Crystal structure of the Epstein-Barr virus (EBV) glycoprotein H/glycoprotein $\mathrm{L}(\mathrm{gH} / \mathrm{gL})$ complex. Proceedings of the National Academy of Sciences of the United States of America 107, 22641-22646.

Maurer, U.E., Zeev-Ben-Mordehai, T., Pandurangan, A.P., Cairns, T.M., Hannah, B.P., Whitbeck, J.C., Eisenberg, R.J., Cohen, G.H., Topf, M., Huiskonen, J.T., et al. (2013). The structure of herpesvirus fusion glycoprotein B-bilayer complex reveals the protein-membrane and lateral protein-protein interaction. Structure 21, 1396-1405.

Melikyan, G.B., Markosyan, R.M., Hemmati, H., Delmedico, M.K., Lambert, D.M., and Cohen, F.S. (2000). Evidence that the transition of HIV-1 gp41 into a six-helix bundle, not the bundle configuration, induces membrane fusion. $J$ Cell Biol 151, 413-423.

Menotti, L., Cerretani, A., Hengel, H., and Campadelli-Fiume, G. (2008). Construction of a fully retargeted herpes simplex virus 1 recombinant capable of entering cells solely via human epidermal growth factor receptor 2 . J Virol 82, 10153-10161.

Milne, R.S., Connolly, S.A., Krummenacher, C., Eisenberg, R.J., and Cohen, G.H. (2001). Porcine HveC, a member of the highly conserved HveC/nectin 1 family, is a functional alphaherpesvirus receptor. Virology 281, 315-328.

Milne, R.S., Nicola, A.V., Whitbeck, J.C., Eisenberg, R.J., and Cohen, G.H. (2005). Glycoprotein D receptor-dependent, low-pH-independent endocytic entry of herpes simplex virus type 1 . J Virol 79, 6655-6663. 
Mizoguchi, A., Nakanishi, H., Kimura, K., Matsubara, K., Ozaki-Kuroda, K., Katata, T., Honda, T., Kiyohara, Y., Heo, K., Higashi, M., et al. (2002). Nectin: an adhesion molecule involved in formation of synapses. J Cell Biol 156, 555-565.

Montalvo, E.A., and Grose, C. (1986). Neutralization epitope of varicella zoster virus on native viral glycoprotein gp118 (VZV glycoprotein gplII). Virology $149,230-241$.

Montgomery, R.I., Warner, M.S., Lum, B.J., and Spear, P.G. (1996). Herpes simplex virus-1 entry into cells mediated by a novel member of the TNF/NGF receptor family. Cell $87,427-436$.

Muggeridge, M.I. (2000). Characterization of cell-cell fusion mediated by herpes simplex virus 2 glycoproteins $\mathrm{gB}, \mathrm{gD}, \mathrm{gH}$ and $\mathrm{gL}$ in transfected cells. $\mathrm{J}$ Gen Virol 81, 2017-2027.

Muggeridge, M.I. (2012). Glycoprotein B of herpes simplex virus 2 has more than one intracellular conformation and is altered by low $\mathrm{pH}$. J Virol 86 , 6444-6456.

Muggeridge, M.I., Grantham, M.L., and Johnson, F.B. (2004). Identification of syncytial mutations in a clinical isolate of herpes simplex virus 2. Virology 328, 244-253.

Musarrat, F., Jambunathan, N., Rider, P.J.F., Chouljenko, V.N., and Kousoulas, K.G. (2018). The Amino Terminus of Herpes Simplex Virus 1 Glycoprotein K ( $\mathrm{gK}$ ) Is Required for gB Binding to Akt, Release of Intracellular Calcium, and Fusion of the Viral Envelope with Plasma Membranes. J Virol 92.

Nakanishi, H., and Takai, Y. (2004). Roles of nectins in cell adhesion, migration and polarization. Biol Chem 385, 885-892.

Nicola, A.V. (2016). Herpesvirus Entry into Host Cells Mediated by Endosomal Low pH. Traffic 17, 965-975.

Nicola, A.V., Hou, J., Major, E.O., and Straus, S.E. (2005). Herpes simplex virus type 1 enters human epidermal keratinocytes, but not neurons, via a pH-dependent endocytic pathway. J Virol 79, 7609-7616.

Nicola, A.V., McEvoy, A.M., and Straus, S.E. (2003). Roles for endocytosis and low $\mathrm{pH}$ in herpes simplex virus entry into HeLa and Chinese hamster ovary cells. J Virol 77, 5324-5332. 
Nicola, A.V., Peng, C., Lou, H., Cohen, G.H., and Eisenberg, R.J. (1997). Antigenic structure of soluble herpes simplex virus (HSV) glycoprotein D correlates with inhibition of HSV infection. J Virol 71, 2940-2946.

Nicola, A.V., Ponce de Leon, M., Xu, R., Hou, W., Whitbeck, J.C., Krummenacher, C., Montgomery, R.I., Spear, P.G., Eisenberg, R.J., and Cohen, G.H. (1998). Monoclonal antibodies to distinct sites on herpes simplex virus (HSV) glycoprotein D block HSV binding to HVEM. J Virol 72, 3595-3601.

Nicola, A.V., and Straus, S.E. (2004). Cellular and viral requirements for rapid endocytic entry of herpes simplex virus. J Virol 78, 7508-7517.

Nishimura, M., and Mori, Y. (2019). Entry of betaherpesviruses. Adv Virus Res 104, 283-312.

Novotny, M.J., Parish, M.L., and Spear, P.G. (1996). Variability of herpes simplex virus $1 \mathrm{gL}$ and anti-gL antibodies that inhibit cell fusion but not viral infectivity. Virology 221, 1-13.

Okubo, Y., Uchida, H., Wakata, A., Suzuki, T., Shibata, T., Ikeda, H., Yamaguchi, M., Cohen, J.B., Glorioso, J.C., Tagaya, M., et al. (2016). Syncytial Mutations Do Not Impair the Specificity of Entry and Spread of a Glycoprotein D Receptor-Retargeted Herpes Simplex Virus. J Virol 90, 11096-11105.

Oliver, S.L., Brady, J.J., Sommer, M.H., Reichelt, M., Sung, P., Blau, H.M., and Arvin, A.M. (2013). An immunoreceptor tyrosine-based inhibition motif in varicella-zoster virus glycoprotein $B$ regulates cell fusion and skin pathogenesis. Proceedings of the National Academy of Sciences of the United States of America 110, 1911-1916.

Oliver, S.L., Sommer, M., Zerboni, L., Rajamani, J., Grose, C., and Arvin, A.M. (2009). Mutagenesis of varicella-zoster virus glycoprotein B: putative fusion loop residues are essential for viral replication, and the furin cleavage motif contributes to pathogenesis in skin tissue in vivo. J Virol 83, 7495-7506.

Oliver, S.L., Yang, E., and Arvin, A.M. (2016). Varicella-Zoster Virus Glycoproteins: Entry, Replication, and Pathogenesis. Curr Clin Microbiol Rep 3, 204-215. 
Ono, E., Amagai, K., Taharaguchi, S., Tomioka, Y., Yoshino, S., Watanabe, Y., Cherel, P., Houdebine, L.M., Adam, M., Eloit, M., et al. (2004). Transgenic mice expressing a soluble form of porcine nectin-1/herpesvirus entry mediator $\mathrm{C}$ as a model for pseudorabies-resistant livestock. Proceedings of the National Academy of Sciences of the United States of America 101, 16150-16155.

Parry, C., Bell, S., Minson, T., and Browne, H. (2005). Herpes simplex virus type 1 glycoprotein $\mathrm{H}$ binds to alphavbeta3 integrins. J Gen Virol 86, 7-10.

Peng, R., Zhang, S., Cui, Y., Shi, Y., Gao, G.F., and Qi, J. (2017). Structures of human-infecting Thogotovirus fusogens support a common ancestor with insect baculovirus. Proceedings of the National Academy of Sciences of the United States of America 114, E8905-E8912.

Peng, T., Ponce de Leon, M., Novotny, M.J., Jiang, H., Lambris, J.D., Dubin, G., Spear, P.G., Cohen, G.H., and Eisenberg, R.J. (1998a). Structural and antigenic analysis of a truncated form of the herpes simplex virus glycoprotein gH-gL complex. J Virol 72, 6092-6103.

Peng, T., Ponce-de-Leon, M., Jiang, H., Dubin, G., Lubinski, J.M., Eisenberg, R.J., and Cohen, G.H. (1998b). The $\mathrm{gH}$-gL complex of herpes simplex virus (HSV) stimulates neutralizing antibody and protects mice against HSV type 1 challenge. J Virol 72, 65-72.

Perez-Romero, P., Perez, A., Capul, A., Montgomery, R., and Fuller, A.O. (2005). Herpes simplex virus entry mediator associates in infected cells in a complex with viral proteins $\mathrm{gD}$ and at least $\mathrm{gH}$. J Virol 79, 4540-4544.

Pertel, P.E., Fridberg, A., Parish, M.L., and Spear, P.G. (2001). Cell fusion induced by herpes simplex virus glycoproteins $\mathrm{gB}, \mathrm{gD}$, and $\mathrm{gH}-\mathrm{gL}$ requires a gD receptor but not necessarily heparan sulfate. Virology 279, 313-324.

Petrovic, B., Leoni, V., Gatta, V., Zaghini, A., Vannini, A., and CampadelliFiume, G. (2018). Dual Ligand Insertion in gB and gD of Oncolytic Herpes Simplex Viruses for Retargeting to a Producer Vero Cell Line and to Cancer Cells. J Virol 92.

Raftery, M.J., Behrens, C.K., Muller, A., Krammer, P.H., Walczak, H., and Schonrich, G. (1999). Herpes simplex virus type 1 infection of activated 
cytotoxic T cells: Induction of fratricide as a mechanism of viral immune evasion. J Exp Med 190, 1103-1114.

Rahn, E., Petermann, P., Hsu, M.J., Rixon, F.J., and Knebel-Morsdorf, D. (2011). Entry pathways of herpes simplex virus type 1 into human keratinocytes are dynamin- and cholesterol-dependent. PloS one 6, e25464.

Richart, S.M., Simpson, S.A., Krummenacher, C., Whitbeck, J.C., Pizer, L.I., Cohen, G.H., Eisenberg, R.J., and Wilcox, C.L. (2003). Entry of herpes simplex virus type 1 into primary sensory neurons in vitro is mediated by Nectin-1/HveC. J Virol 77, 3307-3311.

Roberts, S.R., Ponce de Leon, M., Cohen, G.H., and Eisenberg, R.J. (1991). Analysis of the intracellular maturation of the herpes simplex virus type 1 glycoprotein $\mathrm{gH}$ in infected and transfected cells. Virology 184, 609-624.

Roche, S., Albertini, A.A., Lepault, J., Bressanelli, S., and Gaudin, Y. (2008). Structures of vesicular stomatitis virus glycoprotein: membrane fusion revisited. Cell Mol Life Sci 65, 1716-1728.

Roche, S., Bressanelli, S., Rey, F.A., and Gaudin, Y. (2006). Crystal structure of the low-pH form of the vesicular stomatitis virus glycoprotein G. Science 313, 187-191.

Roche, S., Rey, F.A., Gaudin, Y., and Bressanelli, S. (2007). Structure of the prefusion form of the vesicular stomatitis virus glycoprotein G. Science 315 , 843-848.

Rodger, G., Boname, J., Bell, S., and Minson, T. (2001). Assembly and organization of glycoproteins $\mathrm{B}, \mathrm{C}, \mathrm{D}$, and $\mathrm{H}$ in herpes simplex virus type 1 particles lacking individual glycoproteins: No evidence for the formation of a complex of these molecules. J Virol 75, 710-716.

Rodriguez, J.E., Moninger, T., and Grose, C. (1993). Entry and egress of varicella virus blocked by same anti-gH monoclonal antibody. Virology 196, 840-844.

Rogalin, H.B., and Heldwein, E.E. (2015). Interplay between the Herpes Simplex Virus $1 \mathrm{gB}$ Cytodomain and the gH Cytotail during Cell-Cell Fusion. J Virol 89, 12262-12272. 
Roop, C., Hutchinson, L., and Johnson, D.C. (1993). A mutant herpes simplex virus type 1 unable to express glycoprotein L cannot enter cells, and its particles lack glycoprotein $\mathrm{H}$. J Virol 67, 2285-2297.

Rux, A.H., Lou, H., Lambris, J.D., Friedman, H.M., Eisenberg, R.J., and Cohen, G.H. (2002). Kinetic analysis of glycoprotein $C$ of herpes simplex virus types 1 and 2 binding to heparin, heparan sulfate, and complement component C3b. Virology 294, 324-332.

Rux, A.H., Willis, S.H., Nicola, A.V., Hou, W., Peng, C., Lou, H., Cohen, G.H., and Eisenberg, R.J. (1998). Functional region IV of glycoprotein D from herpes simplex virus modulates glycoprotein binding to the herpesvirus entry mediator. J Virol 72, 7091-7098.

Ryckman, B.J., Jarvis, M.A., Drummond, D.D., Nelson, J.A., and Johnson, D.C. (2006). Human cytomegalovirus entry into epithelial and endothelial cells depends on genes UL128 to UL150 and occurs by endocytosis and low$\mathrm{pH}$ fusion. J Virol 80, 710-722.

Santoro, F., Greenstone, H.L., Insinga, A., Liszewski, M.K., Atkinson, J.P., Lusso, P., and Berger, E.A. (2003). Interaction of glycoprotein $\mathrm{H}$ of human herpesvirus 6 with the cellular receptor CD46. J Biol Chem 278, 25964-25969.

Sarfo, A., Starkey, J., Mellinger, E., Zhang, D., Chadha, P., Carmichael, J., and Wills, J.W. (2017). The UL21 Tegument Protein of Herpes Simplex Virus 1 Is Differentially Required for the Syncytial Phenotype. J Virol 91.

Sathiyamoorthy, K., Hu, Y.X., Mohl, B.S., Chen, J., Longnecker, R., and Jardetzky, T.S. (2016). Structural basis for Epstein-Barr virus host cell tropism mediated by gp42 and gHgL entry glycoproteins. Nature communications 7 , 13557.

Satoh, T., Arii, J., Suenaga, T., Wang, J., Kogure, A., Uehori, J., Arase, N., Shiratori, I., Tanaka, S., Kawaguchi, Y., et al. (2008). PILRalpha is a herpes simplex virus-1 entry coreceptor that associates with glycoprotein B. Cell 132, 935-944.

Saw, W.T., Matsuda, Z., Eisenberg, R.J., Cohen, G.H., and Atanasiu, D. (2015). Using a split luciferase assay (SLA) to measure the kinetics of cell- 
cell fusion mediated by herpes simplex virus glycoproteins. Methods 90 , 68-75.

Schmidt, J., Gerdts, V., Beyer, J., Klupp, B.G., and Mettenleiter, T.C. (2001). Glycoprotein D-independent infectivity of pseudorabies virus results in an alteration of in vivo host range and correlates with mutations in glycoproteins B and $\mathrm{H}$. J Virol 75, 10054-10064.

Schroder, C., and Keil, G.M. (1999). Bovine herpesvirus 1 requires glycoprotein $\mathrm{H}$ for infectivity and direct spreading and glycoproteins $\mathrm{gH}(\mathrm{W} 450)$ and gB for glycoprotein D-independent cell-to-cell spread. J Gen Virol 80 ( Pt 1), 57-61.

Showalter, S.D., Zweig, M., and Hampar, B. (1981). Monoclonal antibodies to herpes simplex virus type 1 proteins, including the immediate-early protein ICP 4. Infection and immunity 34, 684-692.

Shukla, D., Liu, J., Blaiklock, P., Shworak, N.W., Bai, X., Esko, J.D., Cohen, G.H., Eisenberg, R.J., Rosenberg, R.D., and Spear, P.G. (1999). A novel role for 3-O-sulfated heparan sulfate in herpes simplex virus 1 entry. Cell 99, 13-22.

Shukla, S.Y., Singh, Y.K., and Shukla, D. (2009). Role of nectin-1, HVEM, and PILR-alpha in HSV-2 entry into human retinal pigment epithelial cells. Investigative ophthalmology and visual science 50, 2878-2887.

Si, Z., Zhang, J., Shivakoti, S., Atanasov, I., Tao, C.L., Hui, W.H., Zhou, K., Yu, X., Li, W., Luo, M., et al. (2018). Different functional states of fusion protein gB revealed on human cytomegalovirus by cryo electron tomography with Volta phase plate. PLoS Pathog 14, e1007452.

Siekavizza-Robles, C.R., Dollery, S.J., and Nicola, A.V. (2010). Reversible conformational change in herpes simplex virus glycoprotein $B$ with fusionfrom-without activity is triggered by mildly acidic $\mathrm{pH}$. Virology journal 7,352 .

Silverman, J.L., Greene, N.G., King, D.S., and Heldwein, E.E. (2012). Membrane requirement for folding of the herpes simplex virus $1 \mathrm{gB}$ cytodomain suggests a unique mechanism of fusion regulation. J Virol 86 , 8171-8184. 
Silverman, J.L., and Heldwein, E.E. (2013). Mutations in the cytoplasmic tail of herpes simplex virus $1 \mathrm{gH}$ reduce the fusogenicity of $\mathrm{gB}$ in transfected cells. J Virol 87, 10139-10147.

Silverman, J.L., Sharma, S., Cairns, T.M., and Heldwein, E.E. (2010). Fusiondeficient insertion mutants of herpes simplex virus 1 glycoprotein B adopt the trimeric postfusion conformation. J Virol 84, 2001-2012.

Sodeik, B., Ebersold, M.W., and Helenius, A. (1997). Microtubule-mediated transport of incoming herpes simplex virus 1 capsids to the nucleus. $J$ Cell Biol 136, 1007-1021.

Spear, P.G., Manoj, S., Yoon, M., Jogger, C.R., Zago, A., and Myscofski, D. (2006). Different receptors binding to distinct interfaces on herpes simplex virus gD can trigger events leading to cell fusion and viral entry. Virology 344 , 17-24.

Stampfer, S.D., Lou, H., Cohen, G.H., Eisenberg, R.J., and Heldwein, E.E. (2010). Structural basis of local, pH-dependent conformational changes in glycoprotein B from herpes simplex virus type 1. J Virol 84, 12924-12933.

Suenaga, T., Matsumoto, M., Arisawa, F., Kohyama, M., Hirayasu, K., Mori, Y., and Arase, H. (2015). Sialic Acids on Varicella-Zoster Virus Glycoprotein B Are Required for Cell-Cell Fusion. J Biol Chem 290, 19833-19843.

Suenaga, T., Satoh, T., Somboonthum, P., Kawaguchi, Y., Mori, Y., and Arase, H. (2010). Myelin-associated glycoprotein mediates membrane fusion and entry of neurotropic herpesviruses. Proceedings of the National Academy of Sciences of the United States of America 107, 866-871.

Takahashi, K., Nakanishi, H., Miyahara, M., Mandai, K., Satoh, K., Satoh, A., Nishioka, H., Aoki, J., Nomoto, A., Mizoguchi, A., et al. (1999). Nectin/PRR: an immunoglobulin-like cell adhesion molecule recruited to cadherin-based adherens junctions through interaction with Afadin, a PDZ domain-containing protein. J Cell Biol 145, 539-549.

Taylor, J.M., Lin, E., Susmarski, N., Yoon, M., Zago, A., Ware, C.F., Pfeffer, K., Miyoshi, J., Takai, Y., and Spear, P.G. (2007). Alternative entry receptors for herpes simplex virus and their roles in disease. Cell Host Microbe 2, 19-28.

Tiwari, V., O'Donnell, C., Copeland, R.J., Scarlett, T., Liu, J., and Shukla, D. (2007). Soluble 3-O-sulfated heparan sulfate can trigger herpes simplex virus 
type 1 entry into resistant Chinese hamster ovary (CHO-K1) cells. J Gen Virol 88, 1075-1079.

Turner, A., Bruun, B., Minson, T., and Browne, H. (1998). Glycoproteins gB, gD, and $\mathrm{gHgL}$ of herpes simplex virus type 1 are necessary and sufficient to mediate membrane fusion in a Cos cell transfection system. J Virol 72, 873-875.

Tuzmen, C., Cairns, T.M., Atanasiu, D., Lou, H., Saw, W.T., Hall, B.L., Cohen, J.B., Cohen, G.H., and Glorioso, J.C. (2020). Point Mutations in Retargeted gD Eliminate the Sensitivity of EGFR/EGFRvIII-Targeted HSV to Key Neutralizing Antibodies. Mol Ther Methods Clin Dev 16, 145-154.

Uchida, H., Chan, J., Goins, W.F., Grandi, P., Kumagai, I., Cohen, J.B., and Glorioso, J.C. (2010). A double mutation in glycoprotein gB compensates for ineffective gD-dependent initiation of herpes simplex virus type 1 infection. $\mathrm{J}$ Virol 84, 12200-12209.

Vallbracht, M., Backovic, M., Klupp, B.G., Rey, F.A., and Mettenleiter, T.C. (2019). Common characteristics and unique features: A comparison of the fusion machinery of the alphaherpesviruses Pseudorabies virus and Herpes simplex virus. Adv Virus Res 104, 225-281.

Vallbracht, M., Brun, D., Tassinari, M., Vaney, M.C., Pehau-Arnaudet, G., Guardado-Calvo, P., Haouz, A., Klupp, B.G., Mettenleiter, T.C., Rey, F.A., et al. (2017). Structure-function dissection of the Pseudorabies virus glycoprotein B fusion loops. J Virol 92, e01203-01201.

Vallbracht, M., Fuchs, W., Klupp, B.G., and Mettenleiter, T.C. (2018). Functional Relevance of the Transmembrane Domain and Cytoplasmic Tail of the Pseudorabies Virus Glycoprotein $\mathrm{H}$ for Membrane Fusion. J Virol 92, e00376-00318.

Van de Walle, G.R., Peters, S.T., VanderVen, B.C., O'Callaghan, D.J., and Osterrieder, N. (2008). Equine herpesvirus 1 entry via endocytosis is facilitated by alphaV integrins and an RSD motif in glycoprotein D. J Virol 82, 11859-11868.

Vitu, E., Sharma, S., Stampfer, S.D., and Heldwein, E.E. (2013). Extensive mutagenesis of the HSV-1 gB ectodomain reveals remarkable stability of its postfusion form. J Mol Biol 425, 2056-2071. 
Vleck, S.E., Oliver, S.L., Brady, J.J., Blau, H.M., Rajamani, J., Sommer, M.H., and Arvin, A.M. (2011). Structure-function analysis of varicella-zoster virus glycoprotein $\mathrm{H}$ identifies domain-specific roles for fusion and skin tropism. Proceedings of the National Academy of Sciences of the United States of America 108, 18412-18417.

Walker, E.B., Pritchard, S.M., Cunha, C.W., Aguilar, H.C., and Nicola, A.V. (2015). Polyethylene glycol-mediated fusion of herpes simplex type 1 virions with the plasma membrane of cells that support endocytic entry. Virology journal 12, 190.

Wanas, E., Efler, S., Ghosh, K., and Ghosh, H.P. (1999). Mutations in the conserved carboxy-terminal hydrophobic region of glycoprotein $\mathrm{gB}$ affect infectivity of herpes simplex virus. J Gen Virol 80 ( Pt 12), 3189-3198.

Wang, D., and Shenk, T. (2005). Human cytomegalovirus virion protein complex required for epithelial and endothelial cell tropism. Proceedings of the National Academy of Sciences of the United States of America 102, 18153-18158.

Wang, J., Fan, Q., Satoh, T., Arii, J., Lanier, L.L., Spear, P.G., Kawaguchi, Y., and Arase, H. (2009). Binding of herpes simplex virus glycoprotein $B(g B)$ to paired immunoglobulin-like type 2 receptor alpha depends on specific sialylated O-linked glycans on gB. J Virol 83, 13042-13045.

Waning, D.L., Russell, C.J., Jardetzky, T.S., and Lamb, R.A. (2004). Activation of a paramyxovirus fusion protein is modulated by inside-out signaling from the cytoplasmic tail. Proceedings of the National Academy of Sciences of the United States of America 101, 9217-9222.

Warner, M.S., Geraghty, R.J., Martinez, W.M., Montgomery, R.I., Whitbeck, J.C., Xu, R., Eisenberg, R.J., Cohen, G.H., and Spear, P.G. (1998). A cell surface protein with herpesvirus entry activity (HveB) confers susceptibility to infection by mutants of herpes simplex virus type 1 , herpes simplex virus type 2, and pseudorabies virus. Virology 246, 179-189.

Weed, D.J., Dollery, S.J., Komala Sari, T., and Nicola, A.V. (2018). Acidic pH Mediates Changes in Antigenic and Oligomeric Conformation of Herpes Simplex Virus gB and Is a Determinant of Cell-Specific Entry. J Virol 92. 
Whitbeck, J.C., Connolly, S.A., Willis, S.H., Hou, W., Krummenacher, C., Ponce de Leon, M., Lou, H., Baribaud, I., Eisenberg, R.J., and Cohen, G.H. (2001). Localization of the $\mathrm{gD}$-binding region of the human herpes simplex virus receptor, HveA. J Virol 75, 171-180.

Whitbeck, J.C., Muggeridge, M.I., Rux, A.H., Hou, W., Krummenacher, C., Lou, H., van Geelen, A., Eisenberg, R.J., and Cohen, G.H. (1999). The major neutralizing antigenic site on herpes simplex virus glycoprotein $D$ overlaps a receptor-binding domain. J Virol 73, 9879-9890.

Whitbeck, J.C., Peng, C., Lou, H., Xu, R., Willis, S.H., Ponce de Leon, M., Peng, T., Nicola, A.V., Montgomery, R.I., Warner, M.S., et al. (1997). Glycoprotein D of herpes simplex virus (HSV) binds directly to HVEM, a member of the tumor necrosis factor receptor superfamily and a mediator of HSV entry. J Virol 71, 6083-6093.

White, J.M., Delos, S.E., Brecher, M., and Schornberg, K. (2008). Structures and mechanisms of viral membrane fusion proteins: multiple variations on a common theme. Crit Rev Biochem Mol Bio 43, 189-219.

Willis, S.H., Rux, A.H., Peng, C., Whitbeck, J.C., Nicola, A.V., Lou, H., Hou, W., Salvador, L., Eisenberg, R.J., and Cohen, G.H. (1998). Examination of the kinetics of herpes simplex virus glycoprotein $D$ binding to the herpesvirus entry mediator, using surface plasmon resonance. J Virol 72, 5937-5947.

Wilson, D.W., Davis-Poynter, N., and Minson, A.C. (1994). Mutations in the cytoplasmic tail of herpes simplex virus glycoprotein $\mathrm{H}$ suppress cell fusion by a syncytial strain. J Virol 68, 6985-6993.

Wittels, M., and Spear, P.G. (1991). Penetration of cells by herpes simplex virus does not require a low $\mathrm{pH}$-dependent endocytic pathway. Virus Res 18, 271-290.

Wu, P., Reed, W.M., and Lee, L.F. (2001). Glycoproteins H and L of Marek's disease virus form a hetero-oligomer essential for translocation and cell surface expression. Arch Virol 146, 983-992.

Wyss, S., Dimitrov, A.S., Baribaud, F., Edwards, T.G., Blumenthal, R., and Hoxie, J.A. (2005). Regulation of human immunodeficiency virus type 1 envelope glycoprotein fusion by a membrane-interactive domain on the gp41 cytoplasmic tail. JVirol 79, 12231-12241. 
Xing, Y., Oliver, S.L., Nguyen, T., Ciferri, C., Nandi, A., Hickman, J., Giovani, C., Yang, E., Palladino, G., Grose, C., et al. (2015). A site of varicella-zoster virus vulnerability identified by structural studies of neutralizing antibodies bound to the glycoprotein complex gHgL. Proceedings of the National Academy of Sciences of the United States of America 112, 6056-6061.

Yang, E., Arvin, A.M., and Oliver, S.L. (2014). The cytoplasmic domain of varicella-zoster virus glycoprotein $\mathrm{H}$ regulates syncytia formation and skin pathogenesis. PLoS Pathog 10, e1004173.

Yang, E., Arvin, A.M., and Oliver, S.L. (2016). Role for the alphaV Integrin Subunit in Varicella-Zoster Virus-Mediated Fusion and Infection. J Virol 90, 7567-7578.

Yang, F., Lin, S., Ye, F., Yang, J., Qi, J., Chen, Z., Lin, X., Wang, J., Yue, D., Cheng, Y., et al. (2020). Structural Analysis of Rabies Virus Glycoprotein Reveals $\mathrm{pH}$-Dependent Conformational Changes and Interactions with a Neutralizing Antibody. Cell Host Microbe 27, 441-453 e447.

Yin, H.S., Paterson, R.G., Wen, X., Lamb, R.A., and Jardetzky, T.S. (2005). Structure of the uncleaved ectodomain of the paramyxovirus (hPIV3) fusion protein. PNAS 102, 9288-9293.

Yin, H.S., Wen, X., Paterson, R.G., Lamb, R.A., and Jardetzky, T.S. (2006). Structure of the parainfluenza virus $5 \mathrm{~F}$ protein in its metastable, prefusion conformation. Nature 439, 38-44.

Yoon, M., Zago, A., Shukla, D., and Spear, P.G. (2003). Mutations in the N termini of herpes simplex virus type 1 and $2 \mathrm{gDs}$ alter functional interactions with the entry/fusion receptors HVEM, nectin-2, and 3-O-sulfated heparan sulfate but not with nectin-1. J Virol 77, 9221-9231.

Zago, A., Jogger, C.R., and Spear, P.G. (2004). Use of herpes simplex virus and pseudorabies virus chimeric glycoprotein $D$ molecules to identify regions critical for membrane fusion. Proceedings of the National Academy of Sciences of the United States of America 101, 17498-17503.

Zeev-Ben-Mordehai, T., Vasishtan, D., Hernandez Duran, A., Vollmer, B., White, P., Prasad Pandurangan, A., Siebert, C.A., Topf, M., and Grunewald, K. (2016). Two distinct trimeric conformations of natively membraneanchored full-length herpes simplex virus 1 glycoprotein B. Proceedings of 
the National Academy of Sciences of the United States of America 113, 4176-4181.

Zhang, N., Yan, J., Lu, G., Guo, Z., Fan, Z., Wang, J., Shi, Y., Qi, J., and Gao, G.F. (2011). Binding of herpes simplex virus glycoprotein $D$ to nectin-1 exploits host cell adhesion. Nature communications 2, 577.

Zhou, G., and Roizman, B. (2006). Construction and properties of a herpes simplex virus 1 designed to enter cells solely via the IL-13alpha2 receptor. Proceedings of the National Academy of Sciences of the United States of America 103, 5508-5513.

Zhou, G., and Roizman, B. (2007). Separation of receptor-binding and profusogenic domains of glycoprotein $D$ of herpes simplex virus 1 into distinct interacting proteins. Proceedings of the National Academy of Sciences of the United States of America 104, 4142-4146.

Zhou, G., Ye, G.J., Debinski, W., and Roizman, B. (2002). Engineered herpes simplex virus 1 is dependent on IL13Ralpha 2 receptor for cell entry and independent of glycoprotein D receptor interaction. Proceedings of the National Academy of Sciences of the United States of America 99, 15124-15129. 